\title{
The Joint Dynamics of Internal and External Finance*
}

\author{
Andrea Eisfeldt \\ Tyler Muir \\ andrea.eisfeldt@anderson.ucla.edu \\ t-muir@kellogg.northwestern.edu
}

November 11, 2011

\begin{abstract}
We document the fact that at both the aggregate and the firm level, corporations tend to simultaneously raise external finance and accumulate liquid assets. For all but the very largest firms, the aggregate correlation between external finance raised and liquidity accumulation is 0.6 , and the average firm level correlation is 0.2 . This seems puzzling if internal and external finance are substitutes and external finance is costly. In fact, static pecking order intuition predicts that firms will first draw down liquid balances and only then issue external finance. On the other hand, if one believes that the cost of external finance varies over time, then the fact that there appear to be aggregate waves of issuance and savings activity may not be surprising. We show that a simple dynamic model with constant costs of external finance can easily match the observed positive correlation between liquidity accumulation and external finance. We compare the results of this simple model to those from a model which features a shock to the cost of external finance.
\end{abstract}

${ }^{*}$ Finance Area, Anderson School of Management, UCLA. Department of Finance, Kellogg School of Management. We thank Bruce Carlin, Rob Dam, Bob McDonald, Adriano Rampini, Geoffrey Tate, Toni Whited (NBER discussant) and seminar participants at the NBER Corporate Finance Meeting and Kellogg for helpful comments. Eisfeldt gratefully acknowledges financial support from the Fink Center for Finance \& Investments. 


\section{Introduction}

We document the fact that at both the aggregate and the firm level, corporations tend to simultaneously raise external finance and accumulate liquid assets. For all but the very largest firms, the aggregate correlation between external finance raised and liquidity accumulation is 0.6 , and the average firm level correlation is 0.2 . This seems puzzling if internal and external finance are substitutes and external finance is costly. In fact, static pecking order intuition predicts that firms will first draw down liquid balances and only then issue external finance. ${ }^{1}$ On the other hand, if one believes that the cost of external finance varies over time, then the fact that there appear to be aggregate waves of issuance and savings activity may not be surprising.

In this paper, we first show that a simple dynamic model which features a constant cost of external finance, and hence a simple pecking order between internal and external funds, can easily generate the observed positive correlation between external finance and liquidity accumulation. Likewise, because this model features a constant cost of external finance, observing waves of issuance and savings activity does not necessarily imply that costs of external finance are time varying. The constant cost model also replicates the observed procyclical variation in the percentage of firms raising external finance. We then construct a model with a stochastic cost of external finance in order to uncover which other moments might be more informative about aggregate shocks to the cost of external finance. We show that cross sectional moments, such as the cross sectional correlation between liquidity accumulation and external finance, are related to measures of the cost of external finance in the model and in the data.

Following the financial crisis of 2008 and the subsequent "great recession," there has been a renewed interest in the role of costly external finance both in explaining firm level investment,

\footnotetext{
${ }^{1}$ See Myers (1984) p. 581.
} 
and in constructing empirically relevant business cycle models. ${ }^{2}$ However, despite this renewed interest, the fact that financial constraints, or shocks originating in the financial sector, are important for either firm level investment, or business cycle dynamics, is not a foregone conclusion amongst economists. For example, recent work on business cycle accounting which measures the importance of frictions inhibiting optimal consumption, labor, and investment decisions as drivers of business cycle fluctuations in output, investment, and hours, attributes only a tertiary role to frictions inhibiting firm investment. ${ }^{3}$ This may be because what matters for firm investment is the interaction between firm investment opportunities and available funds for investment, and investment opportunities tend to be procyclical. ${ }^{4}$ However, it is important to note that the observed large cross sectional dispersion in firm level productivities suggests that the majority of firm level productivity shocks are firm specific. As a result, even though aggregate productivity is low in recessions, firms at the high end of the distribution can have good investment opportunities.

The empirical literature on business cycles has only recently begun to include quantities describing the financing of corporations. Jermann and Quadrini (forthcoming), and Covas and Den Haan (2011) both document that debt issuances are highly procyclical, and Covas and Den Haan also report procyclical equity issuances. We are the first to incorporate data on firms' liquidity accumulation, as well as their investment, in order to consider the role of pure financing shocks vs. shocks to investment opportunities in explaining firm level and aggregate investment and financing activities. ${ }^{5}$ We argue that looking at the joint dynamics of liquidity accumulation and external finance is useful for examining the role of shocks to the cost of

\footnotetext{
${ }^{2}$ See Jermann and Quadrini (forthcoming), Covas and Den Haan (2011), Bolton et al. (2011), Khan and Thomas (2011), and Hugonnier et al. (2011).

${ }^{3}$ See Chari et al. (2007).

${ }^{4}$ Gomes, Yaron, and Zhang (2003, 2006) use investment based asset pricing to show that frictions inhibiting investment may be more important in good times, when investment opportunities are high.

${ }^{5}$ In contemporanteous work, Warusawitharana and Whited (2011) use a similar idea to argue that equity misvaluation shocks are important explaining firm level financing policies.
} 
external finance, since how firms use funds may help to disentangle financing shocks from shocks that drive investment opportunities.

First, we document the stylized facts regarding the joint dynamics of internal and external finance in the aggregate, as well as at the firm level. At the aggregate level, we describe the aforementioned strong, positive correlation between liquidity accumulation and external finance. Importantly, the strong, positive correlation between liquidity accumulation and external finance at the aggregate level is not simply due to offsetting positions across firms. We show that this same positive correlation describes firm level behavior, especially when one conditions on firms which are raising external finance. When conditioning on firm size, we find that small firms exhibit stronger positive correlations between the accumulation of internal and external finance, both in the model and in the data. Finally, we also document the correlations between liquidity accumulation and investment, and external finance and investment. These correlations are much weaker than those between external finance and liquidity accumulation.

We then build a dynamic model of firm level internal and external finance in which firms are subject to both idiosyncratic and aggregate shocks. We simulate our model, form a panel of data, and evaluate the model's ability to match both individual firm and aggregate moments for the corporate sector. By doing so, we link recent studies of firm level financing, investment, and saving, and models geared toward matching aggregate data. Though our model is partial equilibrium, studying the aggregate implications is still useful for exploring how the behavior of individual firms subject to common shocks affects the aggregate time series for liquidity accumulation, external finance, and investment. Our focus on the joint dynamics of internal and external finance is new relative to the literature on the business cycle properties of debt and equity issuances. ${ }^{6}$ Since internal and external finance are perfect substitutes if the marginal

\footnotetext{
${ }^{6}$ One exception is Eisfeldt and Rampini (2009), which builds an aggregate model of internal and external finance to study the implications of corporate liquidity demand for the observed low return on liquid assets. Covas and Den Haan (2011) focus on debt and equity issuances, but they do note that, empirically, firms tend to both accumulate financial assets and invest when they issue external finance.
} 
costs and benefits of each are equal, studying their joint dynamics seems promising for learning about variation in the cost of external finance.

We first study the implications for external finance issuance and liquidity accumulation from a baseline model of corporate savings adapted from Riddick and Whited (2009). This model is a useful starting point because even without stochastic costs of external finance, it can generate a positive correlation between external finance and liquidity accumulation. Thus, the baseline model is a robust "straw man," which directs us where to look for unique predictions of the model with stochastic costs. The baseline model has three key features, namely, persistent productivity shocks, a fixed cost of external finance, and convex adjustment costs for investment. With these three features, when investment opportunities are good, firms raise more external finance than they need for current investment in order to avoid again paying the fixed cost of external finance. The additional funds raised are accumulated as liquid assets, and used to smooth investment over time. The baseline model is able to generate the observed aggregate correlation between external finance and liquidity accumulation of 0.6 using a fixed cost which implies that aggregate costs of external finance are only $1 \%$ of total proceeds raised. ${ }^{7}$

We compare the data from the baseline model to a version in which the costs of external finance feature an aggregate stochastic component. One important improvement that the stochastic cost model provides is to the level of liquidity accumulation. This is because the stochastic cost is an additional risk and thus increases firms' precautionary demand. Because capital is more productive than liquid assets, it provides a much higher return on average. Thus, if the only reason to accumulate liquidity is to provide funds for accumulating capital, firms have a strong incentive to use capital itself to hedge. The stochastic cost of external finance affects the relative return to liquid assets more than that on physical capital, leading to greater liquidity accumulation.

\footnotetext{
${ }^{7}$ Cummins and Nyman (2004), and Bazdresch (2005) both argue that fixed costs can help to match the lumpy nature of issuances, and note that such lumpiness can cause firms to save some of the proceeds from issuance.
} 
The second improvement of the stochastic cost model over the baseline model is in matching the correlation between external finance and investment, and investment and liquidity accumulation. Because external finance and liquidity accumulation are always driven by variation in investment opportunities in the baseline model, both external finance and liquidity accumulation are strongly positively correlated with investment. In contrast, the empirical correlations between liquidity accumulation and investment, and external finance and investment, are much lower than those implied by the model. Because the stochastic cost induces independent variation in the relative returns to liquidity accumulation and investment, the model with stochastic cost helps to lower the correlation between investment and the financing variables.

Finally, we document the usefulness of using firms' financing and liquidity accumulation decisions in identifying aggregate conditions for the cost of external finance. Financing variables related to the stochastic cost of external finance in our model are empirically correlated with measures of the cost of external finance such as the default spread, and loan officers' reports of lending standards. In the model, the cost of external finance is strongly negatively related to the percentage of firms raising external finance, with a correlation of -0.7. Empirically, the correlation between the default spread and the percentage of firms raising external finance is -0.59 , and the correlation between loan officers' reports of lending standards and the percent of firms raising external finance is -0.47 . Although both of these measures of the cost of external finance are related to credit conditions, we argue that they are likely to be correlated with the overall cost of external finance.

This relationship between measures of the cost of external finance and issuance activity are intuitive, but perhaps not surprising. Thus, we turn to a measure which incorporates the information in firms' policies for internal and external finance. We show that the cross sectional correlation between the amount of external finance which firms raise, and the liquidity they accumulate, is strongly negatively correlated with the cost of external finance in the model and 
in the data. States in which external finance is less costly are states in which it is advantageous for firms to raise external finance and then save the proceeds as cash. When external finance is more costly, the cost of liquidity accumulation exceeds the benefit, and firms tend not to issue and save. Consistent with this intuition from the model, in the data the correlation between the cross sectional correlation between external finance and liquidity accumulation and the default spread is -0.64 . The correlation with loan officers reports of tightening lending standards is -0.58 . Thus, we argue that using the information in the cross section regarding firms' use of external finance may be useful for making inferences about aggregate costs of external finance.

Recent empirical work in corporate finance at the micro level identifies shocks to credit supply by comparing changes in investment policies between firms with different sensitivities to the cost of external finance while controlling for investment opportunities. ${ }^{8}$ These studies highlight the usefulness of cross sectional variation in investment and financing policies to identify aggregate shocks. In our model with stochastic costs of external finance, firms' investment is much more sensitive to their cash position when the cost of external finance is high. Thus, in the model, cross sectional differences in investment for firms with the same investment opportunities but different cash positions indicate high costs of external finance.

The paper proceeds as follows. Section II reviews related literature, Section III outlines the basic stylized facts, Section IV presents the model, Section V simulates the model and compares the moments to the data, and Section VI concludes.

\footnotetext{
${ }^{8}$ Recent papers which identify and important role for credit supply shocks on investment in the recent crisis are Ivashina and Scharfstein (2010), Duchin et al. (2010), Campello et al. (2010), and Almeida et al. (2009). On the other hand, Paravisini et al. (2011) find only small effects of credit supply shocks on trade.
} 


\section{Related Literature}

Several recent papers develop models which use a shock which originates in the financial sector to better match business cycle facts. ${ }^{9}$ Jermann and Quadrini (forthcoming) show how a model with an endogenous credit limit and a shock to capital liquidity can generate realistic business cycles as well as matching the procyclical debt issuance and countercyclical equity issuance which they document using US Flow of Funds data. Covas and Den Haan (2011) show that in Compustat data both debt and equity issuance are procyclical. In Covas and Haan (2011), they develop a model in which countercyclical equity issuance costs are useful for generating both procyclical equity issuance and a countercyclical default rate. ${ }^{10}$ Khan and Thomas (2011) build a quantitative business cycle model in which credit shocks drive aggregate productivity down by inhibiting productive investment reallocation across firms. Hugonnier et al. (2011) build a search theory of external finance and show how idiosyncratic external finance risk affects corporate savings, investment, and payout policy. Bolton et al. (2011) develop a dynamic theory of firm finance and risk management with stochastic financing costs, and show analytically that such costs can increase savings and can delink external finance from investment at the firm level in a model with constant investment opportunities. Our model confirms these effects in a calibrated, quantitative model with stochastic productivity, and we document their empirical relevance.

Despite this renewed interest, the fact that financial constraints, or shocks originating in the financial sector, are important for either firm level investment, or business cycle dynamics, is not a foregone conclusion amongst economists. While Ivashina and Scharfstein (2010), Duchin et al. (2010), Campello et al. (2010), and Almeida et al. (2009) provide evidence

\footnotetext{
${ }^{9}$ These papers build on the seminal contributions of Bernanke and Gertler (1989), Kiyotaki and Moore (1997) and Carlstrom and Fuerst (1997) on the role of financial market conditions on firm investment and business cycle dynamics.

${ }^{10}$ Choe et al. (1993), and Korajczyk and Levy (2003) also study issuances over the business cycle. Both find that equity issuance is procyclical. Korajczyk and Levy (2003) report countercyclical debt issuance.
} 
that the financial crisis hindered external finance and investment activity at the firm level, Paravisini et al. (2011) find only small effects of credit supply shocks on trade. Moreover, Chari et al. (2008) argue that aggregate data do not support the occurrence of a credit crunch and question the appropriateness of government interventions aimed at improving access to external finance. ${ }^{11}$

It is important to note that even if costly external finance is an important driver of investment over the business cycle, it does not necessarily follow that government policies aimed at lowering such costs in recessions are useful. Gomes et al. (2006) point out that the shadow cost of external finance is procyclical in a standard business cycle model with agency costs of external finance. Gomes et al. (2006) estimate an aggregate production based asset pricing model in which the stochastic discount factor varies with the default premium, and find that the estimated shadow cost of funds is procyclical. ${ }^{12}$ This makes sense if the shocks which drive firms' demand for external funds are procyclical. In our model with investment in both liquid assets and physical capital, lowering the cost of external finance without affecting the relative returns to liquid and physical capital will not spur investment in physical capital since firms can instead save funds for when investment opportunities improve. That this is empirically relevant was evident in the financial crisis when government subsidized funding was provided to banks, and banks responded by hoarding the funds instead of by making more new loans.

Our paper is also related to papers which develop dynamic models of corporate saving. Kim et al. (1998) develop a three date model and show that cash accumulation is increasing in the cost of external finance, the variance of future cash flows, and the return on future investment opportunities, but decreasing in the return differential between physical capital and

\footnotetext{
${ }^{11}$ Likewise, Chari et al. (2007) use business cycle accounting to argue that shocks to the cost of installing capital, or to the return on capital, are only of tertiary importance for explaining the US fluctuations output, investment, and employment. However, papers such as Justiniano et al. (2010), and Christiano et al. (2010), assert that such shocks explain a large fraction of business cycle fluctuations.

${ }^{12}$ A related finding in Chari et al. (2007) is that using business cycle accounting it actually appears that financial frictions improved during the great depression.
} 
cash. ${ }^{13}$ Almeida et al. (2004) study the cash flow sensitivity of cash and empirically document a link between the propensity to save out of cash flow and financial constraints. ${ }^{14}$ Riddick and Whited (2009) construct a fully dynamic model of corporate savings and emphasize the importance of uncertainty for determining corporate savings, and argue that in such a model, the propensity to save is not an accurate measure of financial constraints. Thus, the link between financial constraints and investment in financial assets is also unresolved. ${ }^{15}$ Our paper focuses on learning about the role of costly external finance by studying the correlations between external finance, liquidity accumulation, and investment in firm and aggregate level data, and in our model. A contemporaneous paper with a related focus is Warusawitharana and Whited (2011), which uses simulated method of moments to show that equity misvaluation shocks can help explain firm level corporate issuance and savings policies.

Finally, our paper is related to dynamic models of capital structure. The fact that firms tend to simultaneously raise external finance and accumulate liquidity is at odds with standard static pecking order intuition. Static pecking order theories based on Myers (1984) predict that firms will first draw down cash balances and only once these are exhausted will they seek external finance. Thus, such theories predict a counterfactually negative correlation between external finance and liquidity accumulation. Both of our dynamic models feature a pecking order in the sense that internal funds are less costly than external funds, and both models generate the observed positive correlation between external finance and liquidity accumulation. This result is similar to the implications of the models in Hennessy and Whited (2005) and Strebulaev (2007) for the trade off theory of capital structure. Those papers show that data which

\footnotetext{
${ }^{13}$ For a model which focuses on the value of the flexibility of cash for adjusting net leverage instead of funding investment, see Gamba and Triantis (2008).

${ }^{14}$ See also Faulkender and Wang (2006) for evidence that cash is more valuable when held by financially constrained firms. Harford et al. (2011) argue that firms save to insure against refinancing risk and document an inverse relationship between debt maturity and cash holdings which is stronger when credit market conditions are tighter.

${ }^{15}$ For a model which instead focuses on the value of the flexibility of cash for adjusting net leverage, see Gamba and Triantis (2008).
} 
appear to be inconsistent with static trade-off theories of capital structure can be generated by dynamic models in which firms' objectives are based precisely on the trade-off between the tax benefits and distress costs of debt.

\section{Data and Empirics}

Figure 1 plots cash flows to liquid assets vs. cash flows to external finance at the aggregate level. Our main stylized fact clearly emerges: there is a strong positive correlation between flows to liquid assets and flows to external finance. In this section we first briefly describe our data sources and details of our empirical methodology. We also provide a Data Appendix that gives a detailed description of the construction of variables. We then describe our motivating stylized facts in more detail.

Our main data set is annual firm level data from Compustat from 1980-2010. We focus on Compustat data since we are able to analyze firm level, as well as aggregate, facts. When matching the aggregate facts, we show the results obtained using Flow of Funds data are qualitatively similar. Our sample selection criterion closely follows that in Covas and Den Haan (2011).

We use firm level cash flow statements to track corporate flows. We define cash flows to liquid assets as changes in cash and cash equivalents. ${ }^{16}$ Analogously, we define cash flows to investment (in physical capital) as capital expenditures. We do not include acquisitions in our investment measure. Firm level acquisitions are very lumpy, which can bias the correlations we compute. We verify that including acquisitions does not change our aggregate results, since the aggregate series smooths out individual firm lumpiness. We define flows to external finance

\footnotetext{
${ }^{16}$ We do not use the balance sheet measure of cash since the stock measure is affected by acquisitions. Covas and Den Haan (2011) instead remove firms involved in mergers which increase sales by more than $50 \%$. We have checked that our findings are similar using stock measures and the non-merger sample.
} 
as the sum of net flows to debt and net flows to equity, and net external finance raised as the negative of this variable. We define flows to debt as debt reduction plus changes in current debt plus interest paid, less debt issuances, and flows to equity as purchase of common stock plus dividends less sale of common stock. Following Covas and Den Haan (2011), and Fama and French (2005), we also consider using the negative of the change in total liabilities as flows to debt and negative changes in book equity as flows to equity. We find similar results using these stock measures. We focus on the flow measures in the interest of brevity, and since our model does not feature issuances which are not truly "external" like those related to mergers or employee compensation which are emphasized in Fama and French (2005). Finally, we also verify that the results are similar if we just focus on issuances of debt and equity, rather than the total flow.

In our empirical analysis, we normalize variables by current total book assets for firm level and aggregate analysis. However, our results are robust to alternative normalizations as well, such as aggregate output or aggregate gross-value added from the corporate sector. When computing aggregate correlations, we instead normalize by the lag of book assets, to avoid inducing spurious correlation between the series. Book assets are slow moving and fairly acyclical and thus shouldn't induce any trends in our data. We use the Hodrick and Prescott (1997) filter to remove any remaining series trends when computing aggregate correlations, since, for example cash holdings have trended upwards as a share of assets over our sample (Bates et al. (2009)).

Our main analysis drops the top $10 \%$ of firms by asset size. There are several reasons to do this. First, there are data issues with the largest firms. Much of the investment for the largest firms can not be classified as physical or liquid and falls under other assets. The largest firms may have a large amount of investment in unconsolidated subsidiaries. Anecdotally, a firm may raise funds on behalf of a smaller subsidiary. That subsidiary may use the funds 
to build a new factory, or may store the funds as liquid assets. Since we are not able to distinguish these two activities, we are not able to separate uses of funds raised into physical investment and liquid investment, the main goal of this paper. Next, the largest firms tend to have a large share of foreign earnings. Cash accumulation for firms with large foreign earnings may be tainted by tax motives involving repatriation. Also, as Covas and Den Haan (2011) point out, external finance for the largest firms is not representative of the rest of the sample. They show in particular that one incidence of AT\&T raising equity during a recession in 1983 has implications for the cyclicality of aggregate equity issuance. They advocate dropping the top firms because they have an unusually large influence on the aggregate series. Finally, it is possible that the very largest firms face little or no financial constraints and thus do not compare directly to firms in our model. In our model, if firms were not constrained, they would never accumulate liquidity, but simply issue exactly what they needed to fund investment each period.

Table I gives the correlation between liquidity accumulation and external finance by firm size at both the aggregate and firm level. The table confirms that the largest $10 \%$ have a large influence on the aggregate; their inclusion brings the correlation down from 0.6 and significant to 0.12 and insignificant. Nevertheless, the correlation is positive for any firm size groups we consider, with the correlation generally decreasing in firm size. In contrast, the average firm level correlation is always around 0.18 and significant regardless of firm size. Thus firms tend to raise external finance and accumulate liquid assets, both at the firm level and in the aggregate. We also use the Flow of Funds aggregate data to corroborate our main stylized fact. For the Flow of Funds data, we normalize each series by the trend in gross-value added of the corporate sector (computed using the hp-filter), though using total gdp is similar. Here, we face a new data issue because the Flow of Funds data do not do a good job of identifying liquid assets. If we very narrowly define liquid assets as the net acquisition of financial assets minus trade 
receivables minus miscellaneous assets and show a correlation of 0.33 . However, this definition clearly lacks a large part of investment in marketable securities, since the flow of funds data display a counterfactual decrease over time in liquid assets held within the corporate sector. ${ }^{17}$ Therefore, we also compute the correlation including $1 / 3$ of miscellaneous other assets as liquid and find a correlation of 0.38 which is statistically significant. ${ }^{18}$ Overall, the Flow of Funds data corroborates our main finding of a positive correlation.

Firm size is often thought of as a measure of financial constraints. Table II gives the correlations for other measures of constrained firms, and analyzes the correlations with investment as well. We use three measures of constraints: size, whether a firm has a credit rating, and whether a firm pays dividends. We see stronger correlations between liquidity accumulation and external finance for more constrained firms. We also see that the correlation between liquidity accumulation and investment is generally positive, but varies substantially across different cuts of the data. On the other hand, the correlation between investment and external finance is positive and significant for nearly all cases.

Table III displays the cross correlations of the aggregate time series we study for our main sample which drops the top $10 \%$ of firms. We break out the correlation between liquidity accumulation and external finance into correlations with both debt and equity. While we see that the correlation is stronger for equity (0.69) then debt $(0.16)$, both are positive. We also note that investment is more correlated with debt (0.60) then equity $(-0.15)$. This fact has been pointed out by DeAngelo et al. (2010) who argue that debt might be used more frequently for investment. Also, we note that debt drives most of the variation in external finance, with a correlation with external finance of 0.77 vs 0.43 for equity. For parsimony, for almost all of our analysis we choose to focus on the overall correlation with external finance and abstract

\footnotetext{
${ }^{17}$ See Bates et al. (2009).

${ }^{18}$ The decision to use $1 / 3$ of other miscellaneous assets was based on personal communication with staff at the Board of Governors. Their rough estimate using recent IRS data is that about $1 / 3$ of miscellaneous other assets were marketable securities.
} 
from debt vs equity. Although contract terms differ, Covas and Haan (2011) document that both debt and equity issuances are procyclical for all but the very largest firms. Finally, we see that liquidity accumulation, investment, and all forms of external finance are pro-cyclical in the sense that they are positively correlated with cash flows.

\section{Model}

We present a dynamic model of external finance in the spirit of Riddick and Whited (2009) (RW). A given firm maximizes the present value of equity payouts subject to taxes, financial constraints, and investment adjustment costs.

At each date, the risk-neutral firm chooses capital $(k)$ and liquidity $(l)$. The firm earns operating profits $\pi(k, z)$ depending on the realization of aggregate productivity $(z)$ and the current capital stock. Operating profits are taxed at a rate $\tau$ to capture corporate taxes. Similarly, liquid assets are taxed at rate $\tau$ making the total return on liquid assets $1+r(1-\tau)$, where $r$ is the constant risk-free rate.

Letting the "prime" symbol denote next period values, we define investment in physical capital as

$$
i_{k}=k^{\prime}-(1-\delta) k
$$

where $\delta$ is the depreciation rate on capital. Investment is subject to an adjustment cost $\phi_{i}\left(i_{k}, k\right)$. Similarly, we define investment in liquid assets as

$$
i_{l}=\frac{l^{\prime}}{(1+r(1-\tau))}-l
$$


We define flows to external finance $(e)$ as a matter of accounting

$$
e\left(k, k^{\prime}, l, l^{\prime}, z\right) \equiv(1-\tau) \pi(k, z)-i_{l}-i_{k}-\phi_{i}\left(i_{k}, k\right)
$$

In words, flows to external finance are the firms after tax operating profits less investment in liquid assets, investment in capital, and investment adjustment costs. This simply states the identity that cash flows from operations less cash flows to capital must equal cash flows to external finance, where cash flows to capital incorporates both physical and liquid capital. If $e>0$ the firm is paying out funds and if $e<0$ the firm is raising funds. Intuitively, the firm is raising funds when after tax operating profits do not cover purchases of liquid assets, investment in capital, and investment adjustment costs.

Finally, raising external finance is subject to a cost $\phi_{e}(e, \xi)$, where $\xi$ is a (potentially) random variable representing the cost of external finance, and where $\phi_{e}(e, \xi)=0$ whenever $e \geq 0$ and the firm is paying out funds, and $\phi_{e}(e, \xi)<0$ otherwise. We therefore define flows to equity as the residual of the flows to external finance, minus issuance costs. ${ }^{19}$ The firm's objective is simply to maximize the present discounted value of equity. The firms time $t$ maximization problem is then

$$
\max _{\left\{k, l_{j=t, ., \infty}\right.} E_{t}\left[\sum_{j=t}^{\infty}\left(\frac{1}{1+r}\right)^{j-t}\left(e\left(k_{j}, k_{j+1}, l_{j}, l_{j+1}, z_{j}\right)+\phi_{e}\left(e\left(k_{j}, k_{j+1}, l_{j}, l_{j+1}, z_{j}\right), \xi_{j}\right)\right)\right]
$$

Which can be stated recursively as

$$
V(k, l, z, \xi)=\max _{k^{\prime}, l^{\prime}}\left(e\left(k, k^{\prime}, l, l^{\prime}, z\right)+\phi_{e}\left(e\left(k, k^{\prime}, l, l^{\prime}, z\right), \xi\right)+\frac{1}{1+r} E_{t}\left[V\left(k^{\prime}, l^{\prime}, z^{\prime}, \xi^{\prime}\right)\right]\right)
$$

\footnotetext{
${ }^{19}$ While we use the term "flows to equity" we can replace it by "flows to claimholders" since we do not distinguish between debt and equity in the model.
} 
where we denote the value function by $V$.

\section{A. Functional Forms}

We operationalize the model by assuming the following standard functional forms:

$$
\begin{aligned}
\pi & =z k^{\theta} \\
\ln \left(z^{\prime}\right) & =\rho \ln (z)+\epsilon^{\prime} \\
\phi_{i}\left(i_{k}, k\right) & =c k \Phi_{i}+\frac{a}{2}\left(\frac{i_{k}}{k}\right)^{2} k
\end{aligned}
$$

Operating cash flows $(\pi)$ follow the standard "Ak" technology but with decreasing returns to scale. Firm level productivity $(z)$ follows a log-normal AR(1), and investment adjustment costs $(A)$ have both a fixed and convex component, governed by the parameters $\mathrm{c}$ and $\mathrm{a}$, respectively. As is standard in the literature, $\Phi_{i}=0$ whenever $i_{k}=0$ and $\Phi_{i}=1$ otherwise.

Finally, following Riddick and Whited, we assume the following functional form for the cost of external finance

$$
\phi_{e}(e)=\Phi_{e} \xi\left(-\lambda_{0}+\lambda_{1} e-\frac{1}{2} \lambda_{2} e^{2}\right)
$$

where $\Phi_{e}$ is an indicator that takes the value 1 when $e<0$ and 0 otherwise and $\xi$ measures the stochastic costs of external finance. The cost of external finance consists of three components: a fixed, linear and a quadratic cost, governed by the parameters $\lambda_{0}, \lambda_{1}, \lambda_{2}$, respectively. Notice that for $\lambda_{0}, \lambda_{1}, \lambda_{2}>0, \phi_{e}(e)<0$ if and only if $e<0$.

We consider two cases in our model. First, we set $\xi=1$ so the cost of external finance is constant. Second, to capture time-varying costs of external finance, we let $\xi$ follow a log-normal $\operatorname{AR}(1), \ln \left(\xi^{\prime}\right)=c+\gamma \ln (\xi)+\eta^{\prime}$, where $c=\mu_{\xi}(1-\gamma)$. We refer to the latter as the stochastic cost (SC) version of the model, which captures the idea that costs of external finance vary over time. 


\section{B. Optimality Equations, Asset Moments}

We proceed to analyze the maximization problem by combining the first order conditions with the envelope conditions. Thus, in what follows, we analyze the solution for firms with interior investment and financing policies at each date. Due to the fixed costs of investment and external finance, the full solution will exhibit regions of action and inaction.

The first order condition with respect to $\mathrm{k}^{\prime}$ is

$$
\begin{aligned}
\frac{\partial e}{\partial k^{\prime}}\left(1+\phi_{e}^{\prime}(e)\right)+\frac{1}{1+r} E_{t}\left(\frac{\partial V^{\prime}}{\partial k^{\prime}}\right) & =0 \\
\left(1+a \frac{i_{k}}{k}\right)\left(1+\Phi_{e} \xi\left(\lambda_{1}-\lambda_{2} e\right)\right) & =\frac{1}{1+r} E_{t}\left(\frac{\partial V^{\prime}}{\partial k^{\prime}}\right)
\end{aligned}
$$

Using the envelope condition $\frac{\partial V}{\partial k}=\frac{\partial e}{\partial k}\left(1+\phi_{e}^{\prime}(e)\right)$, we have

$$
\begin{aligned}
& \left(1+a\left(\frac{i_{k}}{k}\right)\right)\left(1+\Phi_{e} \xi\left(\lambda_{1}-\lambda_{2} e\right)\right) \\
= & \frac{1}{1+r} E_{t}\left(\left((1-\tau) \theta z^{\prime} k^{\prime \theta-1}+(1-\delta)-c \Phi_{i}+a\left(\frac{i_{k}^{\prime}}{k^{\prime}}\right)\left(\frac{1}{2} \frac{i_{k}^{\prime}}{k^{\prime}}+1-\delta\right)\right)\left(1+\Phi_{e}^{\prime} \xi^{\prime}\left(\lambda_{1}-\lambda_{2} e^{\prime}\right)\right)\right)
\end{aligned}
$$

Rearranging, we have the familiar pricing equation for a risk-neutral investor

$$
1=\frac{1}{1+r} E_{t}\left(R_{k}\right)
$$

where $R_{k}$, the return on capital, is given by

$$
R_{k}=\frac{\left((1-\tau) \theta z^{\prime} k^{\prime \theta-1}+(1-\delta)\left(1+a\left(\frac{i_{k}^{\prime}}{k^{\prime}}\right)\right)-c \Phi_{i}^{\prime}+a\left(\frac{i_{k}^{\prime}}{k^{\prime}}\right)\left(\frac{1}{2} \frac{i_{k}^{\prime}}{k^{\prime}}\right)\right)}{\left(1+a \frac{i_{k}}{k}\right)} \frac{\left(1+\Phi_{e}^{\prime} \xi^{\prime}\left(\lambda_{1}-\lambda_{2} e^{\prime}\right)\right)}{\left(1+\Phi_{e} \xi\left(\lambda_{1}-\lambda_{2} e\right)\right)}
$$


We can understand the return on capital by thinking of the marginal cost and benefit of increasing capital one unit today. Define $R_{k}=$ payoff / cost as the return from this strategy. The payoff, on the numerator, to increasing capital is: a marginal increase in output, some depreciated capital, a larger fixed cost if you invest tomorrow (since you increased capital), and an adjustment cost to investment consideration (which says if you expect investment to be high tomorrow, there is a benefit to increasing capital today since you avoid large convex cost of investment tomorrow). We multiply this by how much a dollar will be worth inside the firm tomorrow (marginal cost of funds). Since the marginal product of capital will be realized as internal funds tomorrow, there is an extra payoff if internal funds are valuable. The cost, in the denominator, is a dollar, plus adjustment costs. We multiply that by how much a dollar is worth inside the firm today.

Since the conditional expected return on capital is a constant, quantities must adjust for this moment to hold. The return is decreasing in investment and increasing in productivity. Thus, the firm will increase investment in high productivity states until this optimality condition holds.

The first order condition with respect to l' is

$$
\begin{aligned}
\frac{\partial e}{\partial l^{\prime}}\left(1+\phi_{e}^{\prime}(e)\right)+\frac{1}{1+r} E_{t}\left(\frac{\partial V^{\prime}}{\partial l^{\prime}}\right) & =0 \\
\frac{1}{1+r(1-\tau)}\left(1+\Phi_{e} \xi\left(\lambda_{1}-\lambda_{2} e\right)\right) & =\frac{1}{1+r} E_{t}\left(\frac{\partial V^{\prime}}{\partial l^{\prime}}\right)
\end{aligned}
$$

Using the envelope condition for $l, \frac{\partial V}{\partial l}=1+\xi \Phi_{e}\left(\lambda_{1}-\lambda_{2} e\right)$, and rearranging yields

$$
1=\frac{1}{1+r} E_{t}\left(R_{l}\right)
$$

where $R_{l}$ the return on liquid assets, is given by 


$$
R_{l}=(1+r(1-\tau)) \frac{1+\Phi_{e}^{\prime} \xi^{\prime}\left(\lambda_{1}-\lambda_{2} e^{\prime}\right)}{1+\Phi_{e} \xi\left(\lambda_{1}-\lambda_{2} e\right)}
$$

The return on liquid assets is made up of two components. The first is simply the risk-free rate earned by liquid assets (the risk-free rate less any taxes paid). The second piece gives the marginal value of a dollar tomorrow versus today. The return on savings will be high when a dollar is more useful tomorrow than it is today.

It is convenient to define the external finance discount factor that governs state-pricing as follows

$$
\mathcal{F}=\frac{1+\Phi_{e}^{\prime} \xi^{\prime}\left(\lambda_{1}-\lambda_{2} e^{\prime}\right)}{1+\Phi_{e} \xi\left(\lambda_{1}-\lambda_{2} e\right)}
$$

Intuitively, the discount factor is the ratio of the marginal value of funds tomorrow versus today. Assets that pay off when the firm is raising costly external finance are more valuable since they provide internal funds. Notice, $\Phi_{e}\left(\lambda_{1}-\lambda_{2} e\right)>0$ if and only if $e<0$. When the firm is not raising external finance, the marginal value of a dollar inside the firm is the same as it is outside the firm. In contrast, when a firm is raising external finance, the marginal value of a dollar inside the firm is greater than one since the marginal value of external funds is greater than one, and optimality will equate these two things. Sensibly, the discount factor is high when the firm raises more funds since in that case the value of liquid assets is particularly high.

Technically, we are in a risk neutral world here, so $E[R]=1+r$, or $\frac{1}{1+r} E[R]=1$. Thus $R_{k}$ and $R_{l}$ are valid returns. However, the risk-neutral firm in some sense behaves as if it is risk averse. If we define $\widehat{R}_{l}, \widehat{R}_{k}$, as the returns to capital and liquidity without external financing costs (the neoclassical case), we can think of the return moments as 


$$
\begin{aligned}
& 1=\frac{1}{1+r} E_{t}\left(\mathcal{F} \widehat{R}_{l}\right) \\
& 1=\frac{1}{1+r} E_{t}\left(\mathcal{F} \widehat{R}_{k}\right)
\end{aligned}
$$

showing that indeed $\mathcal{F}$ acts as a type of external finance induced stochastic discount factor.

\section{Simulation}

We build on the intuition provided in the previous section by solving the model numerically. We show how far the baseline model can go in matching the joint dynamics of internal and external finance, and compare the results to a model with stochastic costs of external finance. We solve the model using standard discrete state space dynamic programming techniques. Specifically, we use the value function iteration method in Ljungqvist and Sargent (2004). The concavity of the value function ensures a solution to this algorithm. The solution method allows us to study the policy function, which tells us the optimal choices of capital and liquidity to choose for any given state. Mathematically, the policy function is a function $h(k, p, z, \xi)=\left(k^{\prime}, p^{\prime}\right)$ that

maps the current state $(k, p, z, \xi)$ into the optimal choice variables $(k \prime, p l)$. Given the policy function, initial levels of capital and liquid assets, and the aggregate shocks, we can simulate a panel of firms, and analyze the data from that panel as in Gomes (2001).

To discretize the state space, we approximate the realization of the productivity shock using standard Gauss-Hermite quadrature techniques (see Tauchen and Hussey (1991)). We choose six possible realizations of the productivity shock and two for the stochastic cost of external finance. For capital and liquid assets, we choose a large enough grid such that the stationary probabilities of being at the upper bound of the grid are negligible, something we verify ex-post. 
Table IV displays our calibration and compares our parameters choices to those in the literature. To allow comparison, we give our parameter choices in the column EM for the baseline non-stochastic version and EMSC for the version with stochastic costs, those from Riddick and Whited in RW, and the benchmark real business cycle parameters in the RBC column. ${ }^{20}$ The parameters are largely standard in the literature. We compare our choice of parameters to those in the dynamic capital structure literature (as in RW) as well as those in the standard real business cycle (RBC) literature. Since we attempt to match both firm level and aggregate facts, we feature a relative mix of the two. In relation to RW, we (i) decrease the production function curvature parameter ${ }^{21}$, (ii) increase the quadratic adjustment costs of investment, while decreasing the fixed cost, (iii) increase the fixed cost to raising external funds while decreasing the linear and quadratic components, (iv) decrease the depreciation rate on capital, and (v) decrease the tax cost of cash. Note, however, that one should consider an appropriate value of the tax cost net of the distress benefit if such trade-off considerations influence cash holdings in the data. For the stochastic cost version (SC), we drop the fixed cost of raising funds to provide contrast with the baseline model where the fixed cost drives the results. ${ }^{22}$ For the linear and quadratic costs in the SC model, we use the parameters in RW. Finally, we calibrate the persistence of the stochastic cost to match the persistence of the annual default spread over our sample period. We assume the stochastic cost is uncorrelated with the aggregate productivity shock, an assumption consistent with our empirical estimates. The empirical correlation between innovations in the default spread and TFP shocks is -0.2 and is not statistically significantly different from zero.

The lower panel of Table IV provides the average realized costs of issuance and investment

\footnotetext{
${ }^{20}$ See for example Cooley and Prescott (1995).

${ }^{21}$ This is consistent with evidence in Cooper and Haltiwanger (2006). We also found that this lower curvature parameter leads to investment volatility and frequencies for disinvestment that are more empirically realistic since both of these moments increase as the production function becomes closer to linear.

${ }^{22}$ We also computed the model with a stochastic fixed cost. The results for most all moments fall between that of the baseline and the presented SC model so we do not show them here.
} 
for the parameters chosen. The average realized cost of issuance is the average cost a firm in our simulation pays when raising funds, as a fraction of the amount of funds raised. For investment, we give the average adjustment cost paid as a fraction of investment. Both the baseline and SC model have low realized average adjustment costs of under 1\%. For the baseline model, the average cost of issuance is $1.7 \%$, while for the SC model it is $8.5 \%$. The latter is roughly consistent with evidence in Hennessy and Whited (2007) who estimate that firms face an issuance cost of $8.3 \%$ on the first million dollars raised.

\section{A. Firm Level Analysis}

We begin our analysis at the firm level. We use the optimal policy function for a given firm to compare the model generated firm level moments to those in the data. We report the relevant moments in Table V. We find a correlation between external finance (-e) and liquidity accumulation of 0.57 (vs 0.18 in the data). To verify that this correlation is generated by simultaneously raising funds and accumulating liquidity, we also show the correlation between an indicator for liquidity accumulation and external finance is 0.64 (vs 0.09 in the data). The model overshoots on this correlation at the firm level, but gets the aggregate correlation exactly right.

We find a slightly positive correlation between liquidity and investment in the model (0.22), while the correlation is near zero in the data (-0.06). Although one might expect liquidity and investment to be negatively correlated, we should note that there are two confounding effects. First, when firms raise funds and invest, they will over-raise and accumulate liquid assets, making the correlation between liquidity and investment positive. However, in subsequent periods the firm will avoid raising costly external funds and choose instead to fund investment with its large liquid balances, causing a negative correlation. Which effect wins out depends on the parameters of the model. We find the average liquid to total assets ratio to be $1 \%$ 
in the model and $11 \%$ in the data. The (unconditional) probability of raising funds is about $15 \%$, roughly a third of the number in the data (43\%). The frequency of issuances is low in the model relative to the data. However, Bazdresch (2005) shows that issuance size is very skewed, with most activity being driven by a small number of larger issuances, and uses this evidence to document financial lumpiness. The level of investment is about $11 \%$ in the model, compared to $7 \%$ in the data, while the correlation between investment and external finance is 0.93 in our model and 0.20 in the data.

The second column gives the results for the model with a stochastic cost of external finance. While most of the moments are similar, the SC model helps with the liquidity accumulation $(6 \%)$, the correlation between an indicator for external finance and liquidity accumulation (0.48), and the correlation between liquidity and investment (0.00).

To better understand the firm level decisions in our model, we plot the policy functions for external finance, investment, and liquidity accumulation in Figures 9, 10, and 11 respectively. In each panel, we fix productivity and plot the optimal policy as a function of current liquidity and capital $(1, \mathrm{k})$. Productivity decreases from left to right across panels, thus the upper left gives the policy in the highest productivity state, while the lower right gives the policy in the lowest productivity state.

We highlight several key features of the model. First, in the higher productivity states the firm is more likely to raise external finance $(e<0)$ for a given cash, capital pair. Intuitively, since productivity is persistent, high productivity states signal good investment opportunities and the firm therefore wants to increase its capital stock. We also see liquid assets increase, particularly in low cash and low capital states. Thus cash accumulations happen simultaneously with raising external finance, and in particular in states where capital is low. In low capital states, firms would like to invest more, but high quadratic adjustment costs prevent them from doing so. They therefore raise a large amount of funds, invest some today, and save 
the rest for the good (expected) investment opportunities tomorrow. The next panel, which plots investment and adjustment costs, mirrors this intuition.

Conversely, the lower panels of each of figure displays the policies for low productivity states. Here, we see the firm raises funds only when capital is extremely low. Similarly, the firm almost always decumulates liquid assets. Investment is typically negative, as the firm looks to sell off unproductive capital and pay out funds. This view is consistent with Jermann and Quadrini (forthcoming) who find that firms pay down debt during contractions. Since large disinvestment is costly (due to large adjustment costs), and cash flows are scarce, the firm pays out by drawing down cash balances when possible.

The policy functions provide two main takeaways: in good times, when capital is productive and investment opportunities are high, firms borrow large amounts of funds to invest smoothly over subsequent periods. Cash balances allow them to smooth investment opportunities. In contrast, in bad times when investment opportunities are scarce, firms pay out to claim holders. Since cash flows are low, and large scale disinvestment is costly, firms will try to do so by decumulating cash balances.

To further understand the model's implied correlations between internal and external finance, and investment, we plot the policy functions as a function of productivity z only. Specifically, we fix both current capital (k) and liquidity (l) and instead plot the policy function as a function only of productivity in Figure 12. We give three panels which have different fixed values of initial capital, thus giving intuition for differences in small, medium, and large firm behavior. In each case, we fix current liquid assets at their median value. Moving from the left to right (lower to higher productivity), we see flows to external funds (e) decrease, liquid balances increase, and investment increases, showing again that both liquidity accumulation and investment are positively correlated with external finance.

Figure 13 gives the policy functions for investment, external finance, and liquidity accumu- 
lation for the model with the stochastic cost. Notably, investment is more sensitive to cash on hand when the cost of external finance is high. Thus, states where investment opportunities are high but raising external finance is costly are states where cash on hand is valuable to fund investment, providing the main role for cash holding. Looking to the policy for external finance, we see that, as expected, the amount raised decreases significantly in the state where the cost of funds is high.

\section{B. Aggregate Analysis}

Our goal is not only to compare firms at the individual level, but also to match the observed aggregate moments and fluctuations of internal and external finance. In doing so, we provide a more rigorous analysis of our model since we ask whether it can match the key business cycle facts regarding the aggregate and cyclical properties of liquidity accumulation and external finance, as well as matching the firm level facts.

For the aggregate analysis, we need aggregate productivity and aggregate cost of external finance shocks that drives business cycle fluctuations. For the model where the cost of external finance is stochastic, we assume that the stochastic costs are driven purely by aggregate shocks. For aggregate productivity, however, we re-interpret the firm level productivity shocks as being made up of two components, an aggregate and a firm specific shock. This re-interpretation has no effect on the firm level decisions, but gives rise to the commonality in variables across firms that we observe. Specifically, we assume for each firm i that there are two productivity shocks: an aggregate $\left(z_{\text {agg }}\right)$ and a firm specific one $\left(z_{i}\right)$. We assume total productivity for a firm $\left(z_{i, t o t}\right)$ 
is the product of the two and that the two series have identical persistence parameters. ${ }^{23}$

$$
\begin{aligned}
z_{i, t o t} & =z_{i} z_{a g g} \\
\pi_{i} & =z_{i, t o t} k_{i}^{\theta} \\
\ln \left(z_{i}^{\prime}\right) & =\rho \ln \left(z_{i}\right)+\epsilon_{i}^{\prime} \\
\ln \left(z_{\text {agg }}^{\prime}\right) & =\rho \ln \left(z_{\text {agg }}\right)+\epsilon_{\text {agg }}^{\prime}
\end{aligned}
$$

Notice $\rho$, the persistence of the shocks, is common at the firm and aggregate level. In this case

$$
\ln \left(z_{i, t o t}\right)=\rho \ln \left(z_{i, t o t}\right)+\epsilon_{i}^{\prime}+\epsilon_{a g g}^{\prime}
$$

Therefore, total productivity follows an $\mathrm{AR}(1)$ in logs, and we may re-interpret the firm level policies as functions of a total (rather than firm specific) shock. We build the correlation of shocks across firms into our simulation and simulate a panel of 1,000 firms. Specifically, we simulate 1,000 idiosyncratic productivity processes, 1 aggregate productivity process, and 1 aggregate stochastic cost process following the persistence and volatility given in Table IV. We then create 1,000 total firm productivity shocks by summing each firm specific and aggregate productivity series and taking the exponential. We simulate 600 years of data, throwing away the first 100 years to avoid any initial dependencies. We then aggregate across firms to form aggregate corporate flows, analogous to our procedure in Compustat.

Figures 1 and 2 plot the aggregate flows to liquid assets against flows to external finance in the data and model, respectively. The results are strikingly similar. The aggregate series for external finance and liquidity accumulation are positively correlated and procyclical. To

\footnotetext{
${ }^{23}$ We used the updated aggregate productivity series from John Fernald's website to estimate the persistence of the aggregate, and the average industry level series. We found each of these to be approximately equal to 0.65 if we include two trend breaks, as advocated in G. and Fernald (2007).
} 
highlight the cyclical properties of external finance that we match in the data, Figures 3 and 4 plot the percentage of firms raising external finance over time along with the state of the economy, measured in terms of GDP growth, both in the data and in our simulations. Both figures show that the extensive margin is important for the procyclical nature of external finance.

We next plot flows to investment with recession indicators in Figure 6 and compare to the actual data in Figure 5. We see strong comovement of each series as in the data (particularly post 1992 in the data). We match the cyclical properties of these series over the business cycle - external finance, investment, and liquidity accumulation tend to rise in booms, when investment opportunities are good, and fall through recessions. Thus, we are able to match not only the correlations, but the business cycle facts of when these flows occur. However, the correlation between investment and external finance, and investment and liquidity accumulation does appear to be higher in the model than in the data, and we discuss this more below.

Table VI supports these results by computing the moments for the aggregated simulated data and the aggregate Compustat data. The correlations between liquidity accumulation and external finance are nearly identical (0.59 in the model vs 0.60 in the data). The average liquid asset to total assets are slightly low (3\% in the model vs $10 \%$ in the data), but the model comes roughly close on average investment to assets ( $8 \%$ to $6 \%$ ). We also find the probability of raising external finance to be about a third as large in simulations as it is in the data (15\% vs $43 \%)$.

Another striking empirical fact is that aggregate corporate investment closely tracks aggregate corporate internal funds. Moreover, aggregate investment rarely exceeds internal funds. Interestingly, this observation has been used both to motivate theories of costly external finance, such as the pecking order (Myers (1984) and Donaldson (1961)), and conversely to 
argue that perhaps frictions between the household and corporate sector are unimportant for corporate investment (Chari et al. (2007)). Chari, et. al. do, however, acknowledge that reallocation of funds within the corporate sector, and frictions therein, may play a role. The model matches the fact that corporate sector is rarely a net receiver of funds - the probabilities of an aggregate corporate shortfall (defined as aggregate corporate funds raised being positive) are about $1 \%$ and $5 \%$ in the model and data, respectively.

Finally, we compute correlations between liquidity accumulation, external finance, and investment with the cyclical component of log GDP. In the model, we find each series to be procyclical, meaning it is positively correlated with GDP. However, in the data, the correlations are much weaker, and in particular liquidity accumulation is not correlated with GDP. However, we note in Figure 1 that liquidity accumulation does tend to fall during recessions.

While the stochastic cost (SC) model leaves most of the moments unchanged, it improves on several areas. In particular, the SC model helps match the average level of liquid assets, and helps to bring down the correlation between liquidity accumulation and investment and external finance and investment. This makes sense, since we have gone from a one-shock model to a model featuring two shocks that are independent. Intuitively, time-varation in the cost of funds gives rise to market timing and hence generates an additional reason to raise funds and accumulate liquidity other than smoothing investment. This helps delink liquidity accumulation and external finance with investment and the additional uncertainty leads to higher average cash holdings. Finally, the SC model helps with the cyclical properties of each series, in terms of correlation with log hp-filtered GDP. As in the data, liquidity accumulation is no longer cyclical in the $\mathrm{SC}$ version, and the cyclicality of external finance and investment are both lowered to be closer to the data.

We next turn to conditional implications of the model. The model implies a stronger correlation between liquidity accumulation and external funds when the firm is raising funds. 
When firms raise funds, they will also accumulate liquidity as they save some of the funds they raise. We aggregate the Compustat data conditional on a firm raising funds and analyze the time-series properties. As in the model, we find a stronger correlation between liquidity accumulation and external finance of 0.74 when firms are raising funds than when they are paying out funds (0.15), suggesting that the strong relation is between saving and raising funds. In the model, this distinction is even stronger, with a correlation of 0.91 for firms raising and 0.15 for those paying out. Table VIII displays these results. Similarly, we find that when firms are raising funds, the correlation between liquidity accumulation and investment and liquidity accumulation and cash flows are both higher - implications supported by the data. Interestingly, we do not find this decrease in correlation between liquidity accumulation and cash flow in the model with stochastic costs, though the other correlations have similar qualitative changes.

We also match the fact that the correlation between liquidity accumulation and external finance is decreasing with firm size. For example, for the smallest $50 \%$ of firms, the correlation is 0.84 in the data vs 0.86 in the model, whereas for the top $10 \%$ of firms the correlations are 0.03 and 0.12 in the data and model respectively (see Table VIII). The policy functions imply that smaller firms have a stronger correlation between external finance and liquidity accumulation for two reasons. First, they typically have more growth opportunities and, second, they have larger costs to raising funds (relative to assets) and hence will hoard more cash to avoid revisiting the capital market.

In the baseline model, fluctuations in raising external finance are driven purely by fluctuations in productivity. However, in the stochastic model external finance is driven by the time-varying cost of finance as well as productivity. We find that, in the data, external finance varies with proxies for time-varying costs, suggesting a role for such costs. We proxy for the time-varying cost empirically using the net $\%$ of loan officers reporting tightening of 
lending standards and the default spread. In the data, the percentage of firms raising external finance is more correlated with the default spread (-0.59) and lending standards $(-0.40)$ than with TFP (0.25). In contrast, the baseline model implies a correlation with TFP of 0.85 and no correlation with time-varying costs. Similarly, we find that the cross-sectional correlation between liquidity accumulation and external finance (which we call XS rho) can uncover the time-varying cost in both the model and the data. Intuitively, if at a given date firms are simultaneously raising funds and saving them, it is likely that costs of raising external finance are low. Empirically we find correlations between XS rho and the the default spread, lending standards, and TFP of $-0.64,-0.58$, and 0.48 , respectively. We plot the cross-sectional correlation against proxies for the cost of external finance in Figures 7 and 8 and give the correlations in Table VII. Thus, we argue that focusing on times when firms simultaneously raise funds and save them (as measured by the cross-sectional correlation) can be informative about aggregate credit conditions.

Given its simplicity, the baseline model does surprisingly well in replicating the joint dynamics of internal and external finance. The model with the stochastic cost improves along some dimensions, but we acknowledge that this may be due to the fact that it introduces another shock, and not due to the specific nature of the external finance shock. We note, however, that other candidate shocks can have counterfactual implications. A simple shock to costs (eg. operating leverage) may lead to countercyclical issuances since cash flows are low in recessions. Similarly, uncertainty shocks may lead to higher savings for precautionary reasons in bad times. More importantly, carefully identified studies of differences in changes in investment across firms that are more and less dependent on external finance show that credit supply shocks do affect firm level investment. The close correlation with proxies for costs of external finance in the data and those implied by our model (Figure 7) give further support to these costs as drivers of fluctuations in the economy. Thus, it makes sense to investigate 
the ability of such shocks to match the aggregate moments describing the joint dynamics of internal and external finance. By examining the policy for investment in the SC model, one can see that the "difference in differences" approach to identifying shocks makes sense for the model data too. Figure 13 presents the investment policy function for the highest two productivity states, for the high and low cost of external finance states. First, note that investment is only materially affected by the cost for firms with the highest productivity. Second, for the highest productivity state, the investment policy only materially depends on the firm's cash position when the cost of external finance is high. Thus, if one conditioned on firms with high productivity, and observed investment before and after a shock which increased the cost of external finance, the relatively larger decline in investment by firms with small cash balances relative to large cash balances would be indicative of the cost shock.

\section{Conclusion}

We document that liquidity accumulation and external finance are positively correlated at the firm level, and in the aggregate. The strong, positive aggregate correlation between liquidity accumulation and external finance is striking. We show that a very simple model which features persistent productivity shocks, a fixed cost of external finance, and a convex investment adjustment cost can generate empirically realistic aggregate time series for liquidity accumulation and external finance. This simple model generates the observed strong aggregate correlation between the two series, as well as the observed strongly procyclical series for the fraction of firms raising external finance. In order to evaluate the contribution of a shock to the cost of external finance to the business cycle dynamics of liquidity accumulation, external finance, and investment, we compare our results from the baseline model to those from a model featuring a stochastic cost of external finance. The model with the stochastic cost replicates the 
success of the baseline model on most measures, and improves on the dimensions of liquidity accumulation, and the relatively low correlation between external finance and investment, and liquidity accumulation and investment. We find variables which proxy for the stochastic cost of external finance in the model, such as the percentage of firms raising external finance, and the cross sectional correlation between external finance and liquidity accumulation, and show that these are highly correlated with empirical measures of the cost of external finance.

\section{References}

Heitor Almeida, Murillo Campello, and Michael S. Weisbach. The cash flow sensitivity of cash. The Journal of Finance, 59(4):1777-1804, 2004.

Heitor Almeida, Murillo Campello, Bruno Laranjeira, and Scott Weisbenner. Corporate debt maturity and the real effects of the 2007 credit crisis. Working Paper 14990, National Bureau of Economic Research, 2009.

Thomas W. Bates, Kathleen M. Kahle, and Rene Stulz. Why Do U.S. Firms Hold so Much More Cash than They Used to? Journal of Finance, 64(5):1985-2021, 2009.

Santiago Bazdresch. Financial Lumpiness and Investment. Working Paper, 2005.

Ben Bernanke and Mark Gertler. Agency costs, net worth, and business fluctuations. The American Economic Review, 79(1):pp. 14-31, 1989.

Patrick Bolton, Hui Chen, and Neng Wang. Market timing, investment, and risk management. (16808), 2011.

Murillo Campello, John R. Graham, and Campbell R. Harvey. The real effects of financial 
constraints: Evidence from a financial crisis. Journal of Financial Economics, 97(3):470 $487,2010$.

Charles T. Carlstrom and Timothy S. Fuerst. Agency costs, net worth, and business fluctuations: A computable general equilibrium analysis. The American Economic Review, 87(5):pp. 893-910, 1997.

V. V. Chari, Patrick J. Kehoe, and Ellen R. McGrattan. Business cycle accounting. Econometrica, 75(3):781-836, 2007.

V.V. Chari, Lawrence Christiano, and Patrick J. Kehoe. Facts and myths about the financial crisis of 2008. Working Paper, Federal Reserve Bank of Minneapolis, 2008.

Hyuk Choe, Ronald W. Masulis, and Vikram Nanda. Common stock offerings across the business cycle: Theory and evidence. Journal of Empirical Finance, 1(1):3 - 31, 1993.

Lawrence J. Christiano, Roberto Motto, and Massimo Rostagno. Financial Factors in Economic Fluctuations. Working Paper, 2010.

Thomas F. Cooley and Edward C. Prescott. Economic growth and business cycles. In: Cooley, T.F. (Ed.), Frontiers of Business Cycle Research. Princeton University Press, Princeton, pages pp. 1-38, 1995.

Russell W. Cooper and John C. Haltiwanger. On the nature of capital adjustment costs. Review of Economic Studies, 73(3):611-633, 2006.

Francisco Covas and Wouter J. Den Haan. The cyclical behavior of debt and equity finance. The American Economic Review, 101(2):877-899, 2011.

Francisco Covas and Wouter J. Den Haan. The role of debt and equity finance over the business cycle. Working Paper, 2011. 
Jason G. Cummins and Ingmar Nyman. Optimal investment with fixed financing costs. Finance Research Letters, 1(4):226 - 235, 2004.

Harry DeAngelo, Linda DeAngelo, and Toni M. Whited. Capital Structure Dynamics and Transitory Debt. Working Paper, 2010.

Gordon Donaldson. Corporate debt capacity. Division of Research Graduate School of Business, Harvard University, Boston, Mass., 1961.

Ran Duchin, Oguzhan Ozbas, and Berk A. Sensoy. Costly external finance, corporate investment, and the subprime mortgage credit crisis. Journal of Financial Economics, 97(3):418 $-435,2010$.

Andrea L. Eisfeldt and Adriano A. Rampini. Financing Shortfalls and the Value of Aggregate Liquidity. Northwestern Working Paper, 2009.

Eugene F. Fama and Kenneth R. French. Financing decisions: who issues stock? Journal of Financial Economics, 76(3):549 - 582, 2005.

Michael Faulkender and Rong Wang. Corporate financial policy and the value of cash. The Journal of Finance, 61(4):pp. 1957-1990, 2006.

John G. and Fernald. Trend breaks, long-run restrictions, and contractionary technology improvements. Journal of Monetary Economics, 54(8):2467 - 2485, 2007.

Andrea Gamba and Alexander Triantis. The value of financial flexibility. The Journal of Finance, 63(5):2263-2296, 2008.

Joao F. Gomes, Amir Yaron, and Lu Zhang. Asset pricing implications of firms' financing constraints. Review of Financial Studies, 19(4):1321-1356, 2006. 
Joao F. Gomes. Financing investment. The American Economic Review, 91(5):pp. 1263-1285, 2001.

Jarrad Harford, Sandy Klasa, and William F. Maxwell. Refinancing Risk and Cash Holdings. Working Paper, 2011.

Christopher A. Hennessy and Toni M. Whited. Debt dynamics. The Journal of Finance, 60(3):1129-1165, 2005.

Christopher A. Hennessy and Toni M. Whited. How costly is external financing? evidence from a structural estimation. Journal of Finance, 62(4):1705-1745, 082007.

Robert J. Hodrick and Edward C. Prescott. Postwar u.s. business cycles: An empirical investigation. Journal of Money, Credit and Banking, 29(1):pp. 1-16, 1997.

Julien N. Hugonnier, Semyon Malamud, and Erwan Morellec. Capital supply uncertainty, cash holdings, and investment. Working Paper, 2011.

Victoria Ivashina and David Scharfstein. Bank lending during the financial crisis of 2008. Journal of Financial Economics, 97(3):319 - 338, 2010.

Urban Jermann and Vincenzo Quadrini. Macroeconomic effects of financial shocks. The American Economic Review, forthcoming.

Alejandro Justiniano, Giorgio E. Primiceri, and Andrea Tambalotti. Investment shocks and business cycles. Journal of Monetary Economics, 57(2):132 - 145, 2010.

Aubhik Khan and Julia K. Thomas. Credit shocks and aggregate fluctuations in an economy with production heterogeneity. Working Paper, 2011. 
Chang-Soo Kim, David C. Mauer, and Ann E. Sherman. The determinants of corporate liquidity: Theory and evidence. Journal of Financial and Quantitative Analysis, 33(03):335$359,1998$.

Nobuhiro Kiyotaki and John Moore. Credit cycles. Journal of Political Economy, 105(2):pp. 211-248, 1997.

Robert A Korajczyk and Amnon Levy. Capital structure choice: macroeconomic conditions and financial constraints. Journal of Financial Economics, 68(1):75 - 109, 2003.

Lars Ljungqvist and Thomas J. Sargent. Recursive Macroeconomic Theory, 2nd Edition, volume 1 of MIT Press Books. The MIT Press, 2004.

Stewart C. Myers. Capital structure puzzle. The Journal of Finance, 39(3):pp. 575-592, 1984.

Daniel Paravisini, Veronica Rappoport, Philipp Schnabl, and Daniel Wolfenzon. Dissecting the effect of credit supply on trade: Evidence from matched credit-export data. Working Paper, 2011.

Leigh A. Riddick and Toni M. Whited. The corporate propensity to save. The Journal of Finance, 64(4):1729-1766, 2009.

Ilya A. Strebulaev. Do tests of capital structure theory mean what they say? The Journal of Finance, 62(4):1747-1787, 2007.

George Tauchen and Robert Hussey. Quadrature-based methods for obtaining approximate solutions to nonlinear asset pricing models. Econometrica, 59(2):pp. 371-396, 1991.

Missaka Warusawitharana and Toni M Whited. Equity market misvaluation and firm financial policies. Working Paper, 2011. 


\section{Data Appendix}

\section{Data Appendix}

Our data construction closely follows Covas and Den Haan (2011). Our primary source of data is the Compustat fundamentals annual file. Our main results use data from 1980-2010. We exclude financials, utilities and firms with SIC codes starting with 9. We also exclude firms with missing assets, equity, debt, and those with missing or negative PPE and cash balances. As in Covas and Den Haan (2011), we also remove GM, GE, Chrysler, and Ford, since these firms were the most affected by the accounting change in 1988 requiring firms to consolidate the balance sheets of their wholly owned subsidiaries.

\section{Computstat Data}

We first define liquidity accumulation, investment, and external finance as:

Investment $=\mathrm{CAPEX}$ (Capital Expenditures)

Liquidity Accumulation $=$ CHECH (Cash and cash equivalents, change)

External Finance $=-\left(C F_{D}+C F_{E}\right)$

For flows to debt and equity and operating cash flows we use the statement of cash flows: For statments of cash flows:

$C F_{O}=$ Income before extra items $(\mathrm{IBC})+$ Depreciation and amortization $(\mathrm{DPC})+$ EI \& Discontinued Oper (XIDOC) + Deferred Taxes (TXDC) + Equity in net loss (ESUBC) + Funds from operations: other (FOPO) + Income taxes: accrued inc(dec) $(\mathrm{TXACH})+$ Assets \& Liab: other (net change) $(\mathrm{AOLOCH})+$ Accounts receivable dec(inc) $(\mathrm{RECCH})+$ Inventory $\operatorname{dec}(\mathrm{inc})(\mathrm{INVCH})+$ Accounts payable inc $(\mathrm{dec})(\mathrm{APALCH})+$ Interest paid (net) (XINT) $C F_{E}=-$ Sale of common and pref. stock (SSTK)+ Purchase of common and pref. stock $($ PRSTKC) + Cash dividends (DV) 
$C F_{D}=$ - Long-term debt issuance (DLTIS) + Long-term debt: reduction (DLTR) + Changes in current debt $(\mathrm{DLCCH})+$ Interest paid (net) (XINT)

For statments by source and use of funds:

$C F_{O}=$ Income before extra items $($ IBC $)+$ Depreciation and amortization $($ DPC $)+$ EI \& Discontinued Oper (XIDOC) + Deferred Taxes (TXDC) + Equity in net loss (ESUBC) + Funds from operations: other (FOPO)+ Interest expense (XINT)

$C F_{E}=-$ Sale of common and pref. stock (SSTK)+ Purchase of common and pref. stock $($ PRSTKC) + Cash dividends (DV)

$C F_{D}=$ - Long-term debt issuance (DLTIS) + Long-term debt: reduction (DLTR) + Changes in current debt $(\mathrm{DLCCH})+$ Interest paid (net) $(\mathrm{XINT})$

For working capital statementes:

$C F_{O}=$ Income before extra items $(\mathrm{IBC})+$ Depreciation and amortization $(\mathrm{DPC})+$ EI \& Discontinued Oper $($ XIDOC) + Deferred Taxes $($ TXDC) + Equity in net loss (ESUBC) + Funds from operations: other (FOPO)+ Interest expense (XINT)

$C F_{E}=-$ Sale of common and pref. stock (SSTK)+ Purchase of common and pref. stock $($ PRSTKC) + Cash dividends (DV)

$C F_{D}=$ - Long-term debt issuance (DLTIS) + Long-term debt: reduction (DLTR) + Changes in current debt $(\mathrm{DLCCH})+$ Interest paid (net) $(\mathrm{XINT})$

For cash statements by activity:

$C F_{O}=$ Income before extra items $(\mathrm{IBC})+$ Depreciation and amortization $(\mathrm{DPC})+$ EI \& Discontinued Oper $($ XIDOC) + Deferred Taxes $($ TXDC) + Equity in net loss (ESUBC) + Funds from operations: other (FOPO)+ Interest expense (XINT)

$C F_{E}=-$ Sale of common and pref. stock (SSTK)+ Purchase of common and pref. stock 
$($ PRSTKC) + Cash dividends (DV)

$C F_{D}=$ - Long-term debt issuance (DLTIS) + Long-term debt: reduction (DLTR) + Changes in current debt $(\mathrm{DLCCH})+$ Interest paid (net) $(\mathrm{XINT})$

\section{Flow of Funds Data}

We use annual data from the electronic ASCII flow of funds seasonally adjusted annual rates table F.102 available at

http://www.federalreserve.gov/Releases/z1/Current/data.htm.

Refer to the coded tables for definitions and relationships between entries. Codes appear in parentheses after variable names. Interest payments, not reported in table F.102, are from NIPA table 1.14 line 25 "Net interest and miscellaneous payments" for nonfinancial corporate business.

$C F_{O}=($ Total internal funds + IVA $)($ FA1060000105) - Discrepancy $($ FA107005005) + Net dividends (FA106120005) + Trade payables (FA103170005) + Taxes payable (FA103178000) + Miscellaneous liabilities (FA103190005) - Trade receivables (FA103070005) + NIPA interest $C F_{D}=$ Commercial paper $($ FA103169700) + Mortgages (FA103065003) - Credit market instruments (FA104104005) + NIPA interest

$C F_{E}=$ Net dividends (FA106120005) - Net new equity issues (FA103164003)

Liquidity Accumulation $=$ Net acquisition of financial assets - Commercial paper - Mortgages - Trade receivables - Other Assets

Investment $=$ Capital expenditures 


\section{Other Data}

The following series used can be found in the FRED database at the St Louis Fed website. $G d p=$ Real gross domestic product

Default Spread= Difference between Moody's Seasoned Baa and Aaa yield. We use end of year values.

Lending Standards $=$ Net Percentage of Domestic Respondents Tightening Standards for Commercial and Industrial Loans Large and Medium Firms (DRTSCILM). We use end of year values.

Finally, we obtain TFP data from John Fernald. 


\section{Figures, Tables}




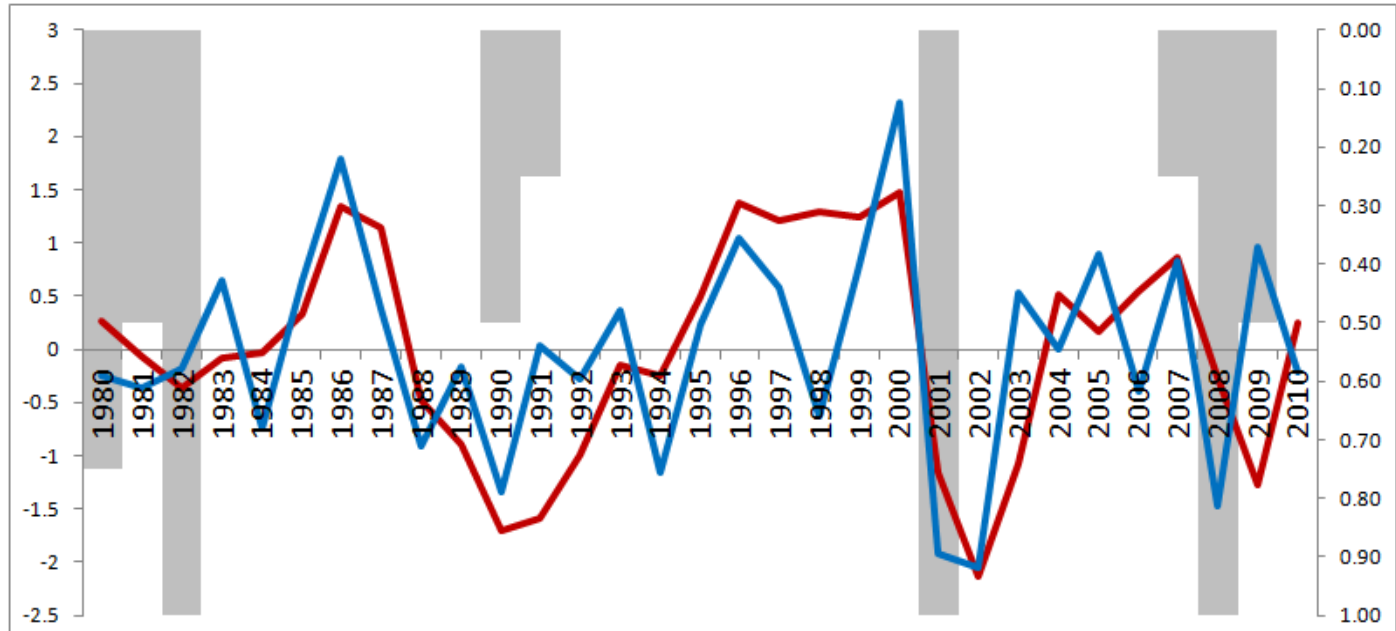

Share of Quarters in Recession —External Finance — Liquidity Accumulation

Figure 1: The figure plots aggregate accumulation of liquid assets against aggregate external finance. We use annual data from Compustat, excluding the largest $10 \%$ of firms. The data are normalized by lagged assets and HP-filtered. Gray bars are the fraction of quarters the economy is in a recession in the given year (right axis).

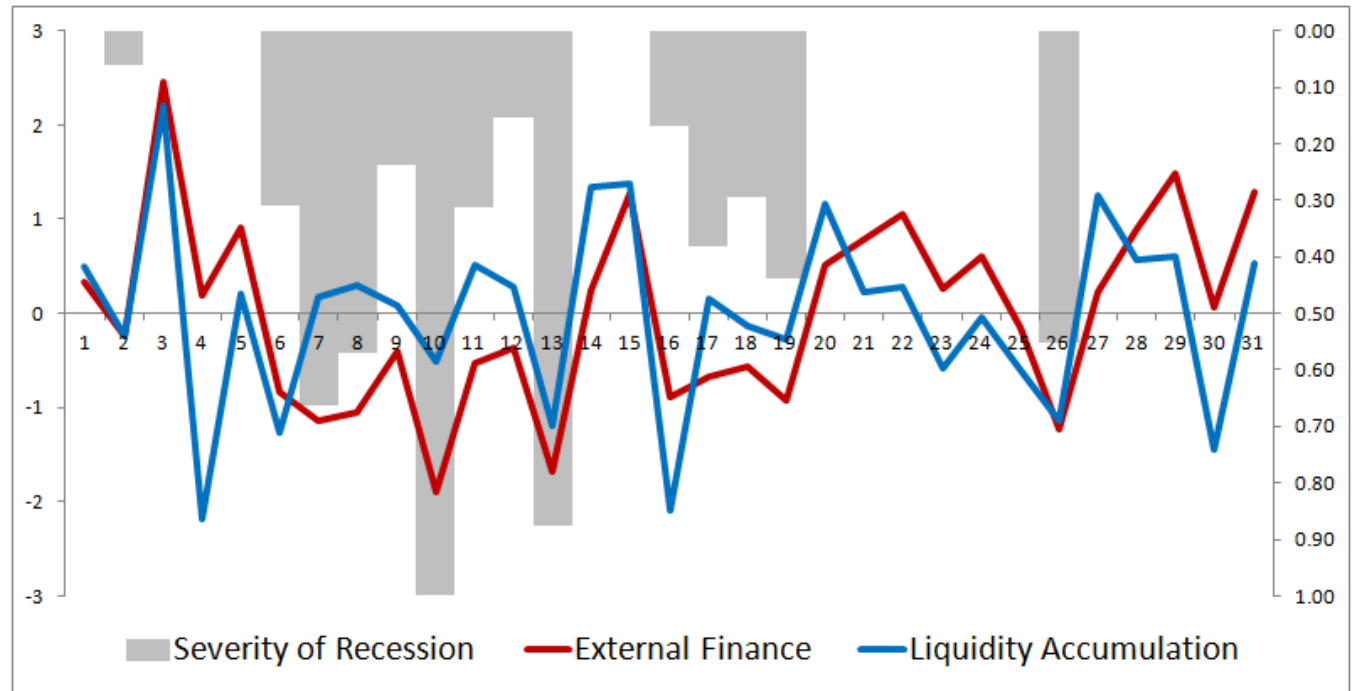

Figure 2: The figure plots aggregated data from a simulation of 1000 firms using 30 years of data. We plot aggregate accumulation of liquid assets against aggregate external finance. Both series are normalized by total assets. Gray bars indicate when gdp growth falls below trend (right axis). 




Figure 3: This figure plots the time-series of the percentage of firms raising external finance over the business cycle, measured as the growth rate of gdp. The firm level data are from Compustat. A firm is raising external finance if net flows to external finance are negative. Gray bars are the fraction of quarters the economy is in a recession in the given year (right axis).

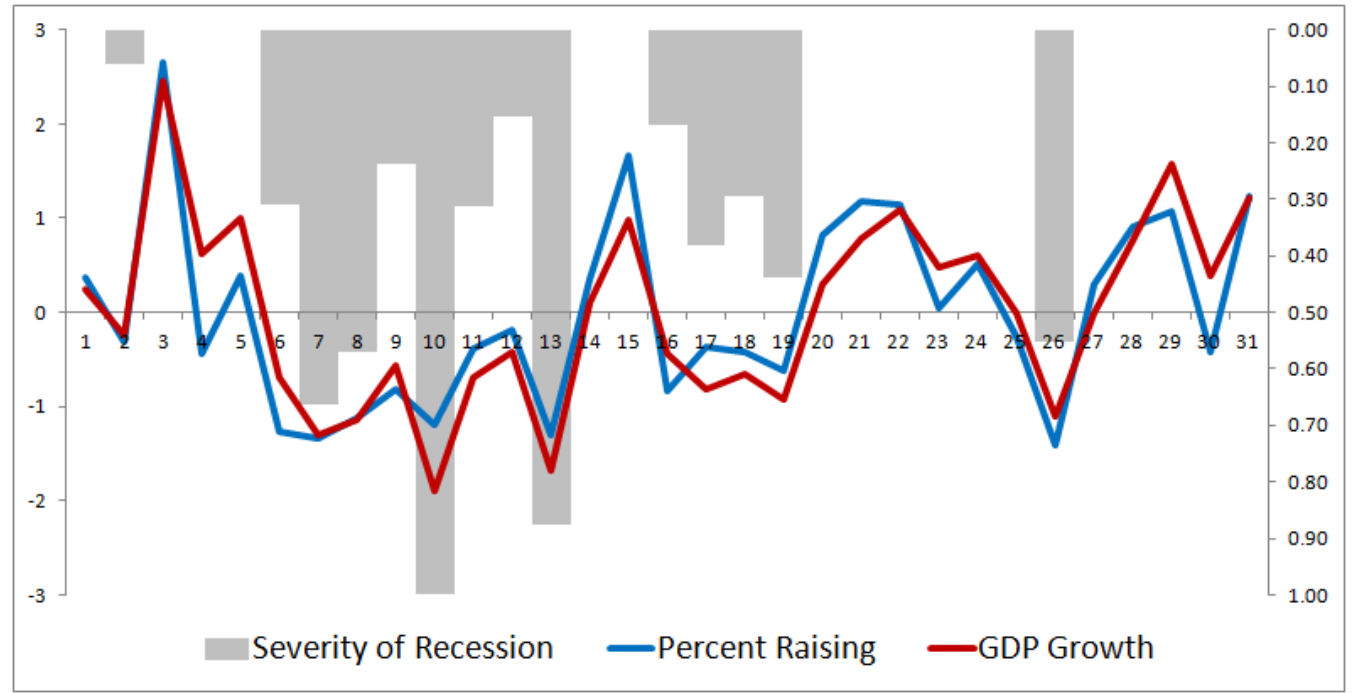

Figure 4: This figure plots the percentage of firms raising external finance over the business cycle. The cycle is measured by Ak, the aggregate productivity state. The simulation uses aggregate data from 1000 simulated firms using 30 years of simulated data. Gray bars indicate when gdp growth falls below trend (right axis). 


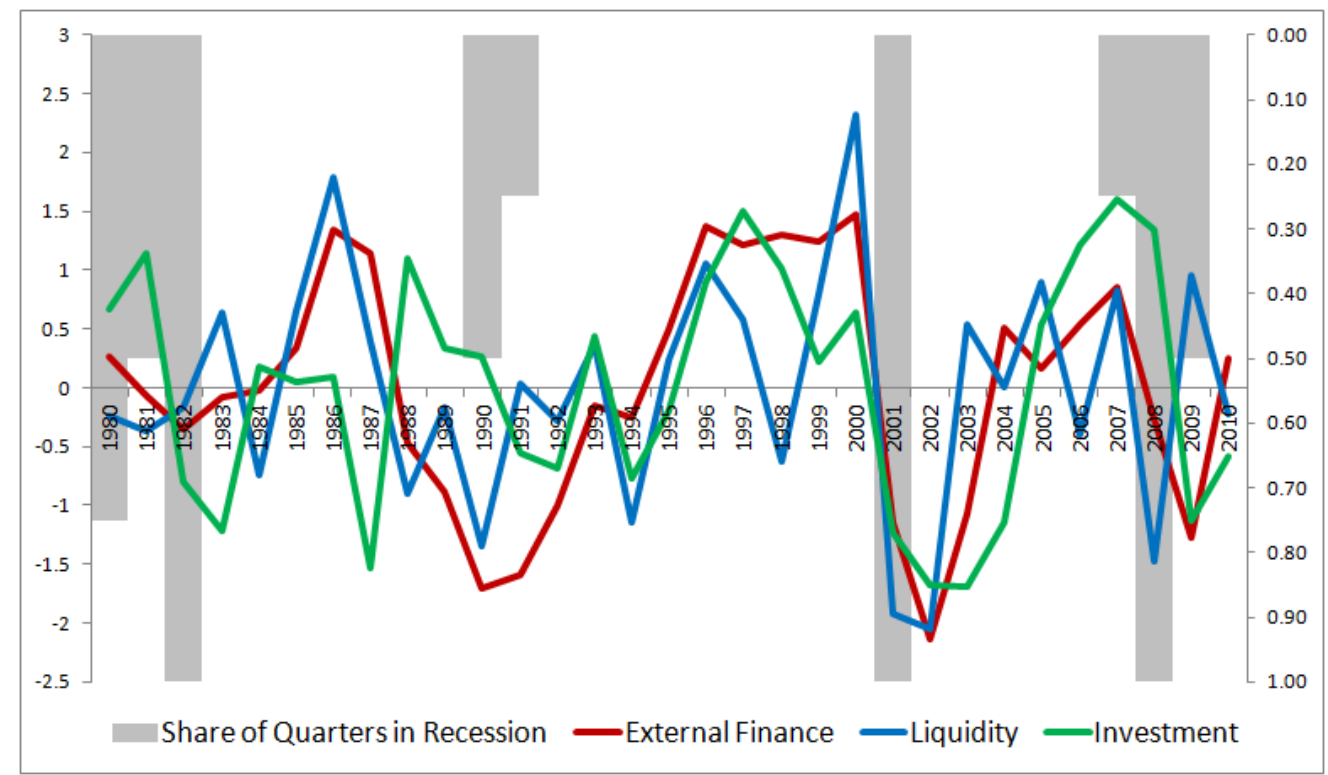

Figure 5: We plot aggregate liquidity accumulation, external finance, and investment aggregated from Compustat (all normalized by lagged assets). Gray bars are the fraction of quarters the economy is in a recession in the given year (right axis).

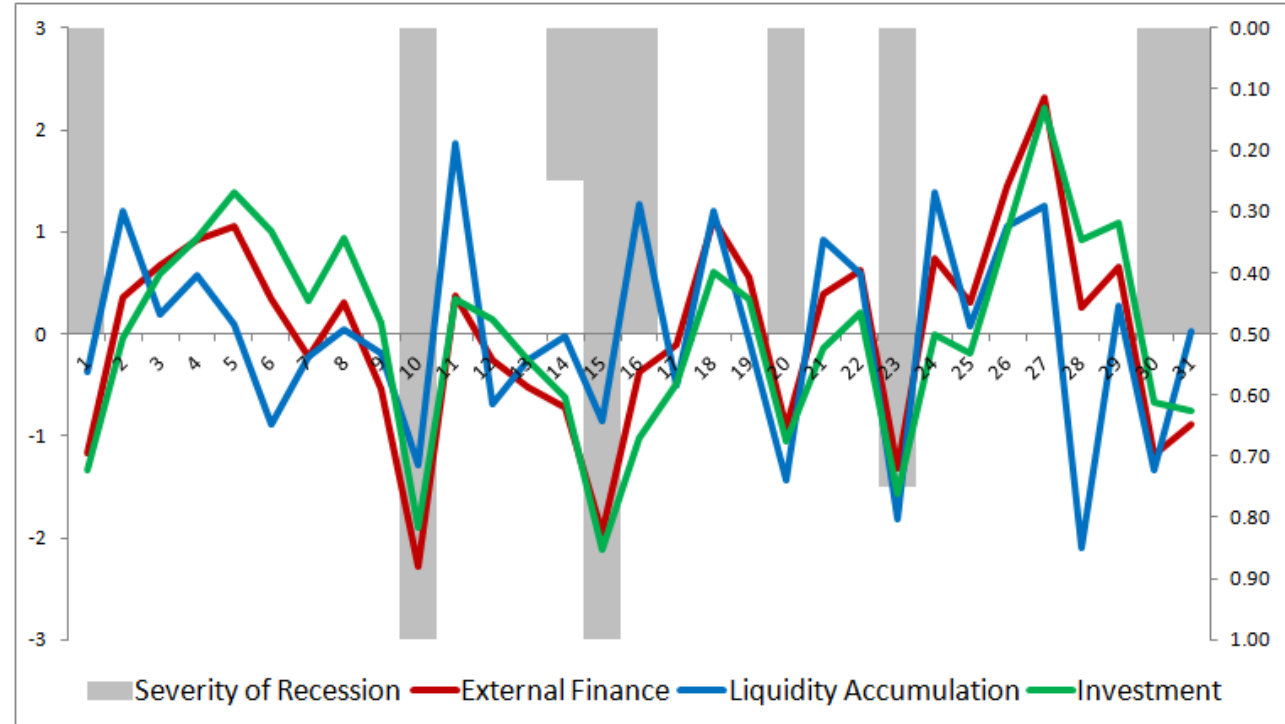

Figure 6: We plot simulated aggregate liquidity accumulation, external finance, and investment, and gdp aggregated from simulated data. The simulation uses aggregate data from 1000 simulated firms using 30 years of simulated data. Gray bars indicate when gdp growth falls below trend (right axis). 


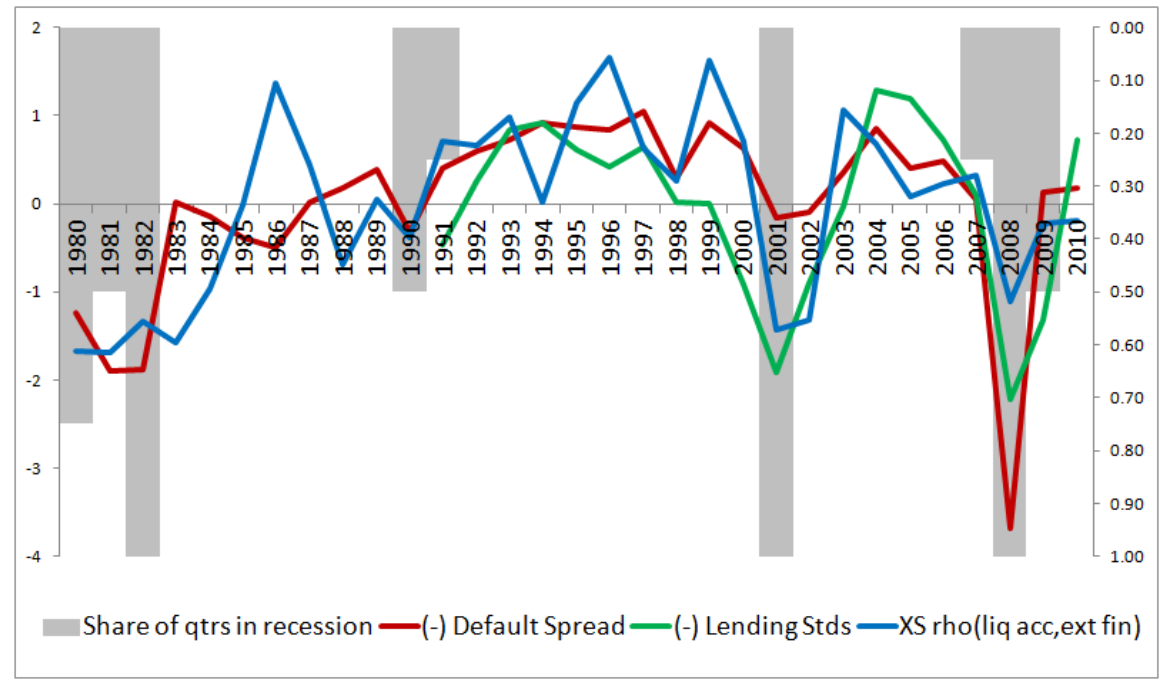

Figure 7: We plot the the cross-sectional correlation between liquidity and external finance (XS rho). In our model, this proxy reveals times when external finance is expensive. We also plot the negatives of the Moody's Baa-Aaa rate (Default Spread) and the net \% of banks tightening lending standards for large and medium firms (Lending Standards), empirical proxies for the cost of external finance. The correlation between XS rho and the negative of the Default spread and Lending Standards are 0.64 and 0.58, respectively. Gray bars are the fraction of quarters the economy is in a recession in the given year (right axis).

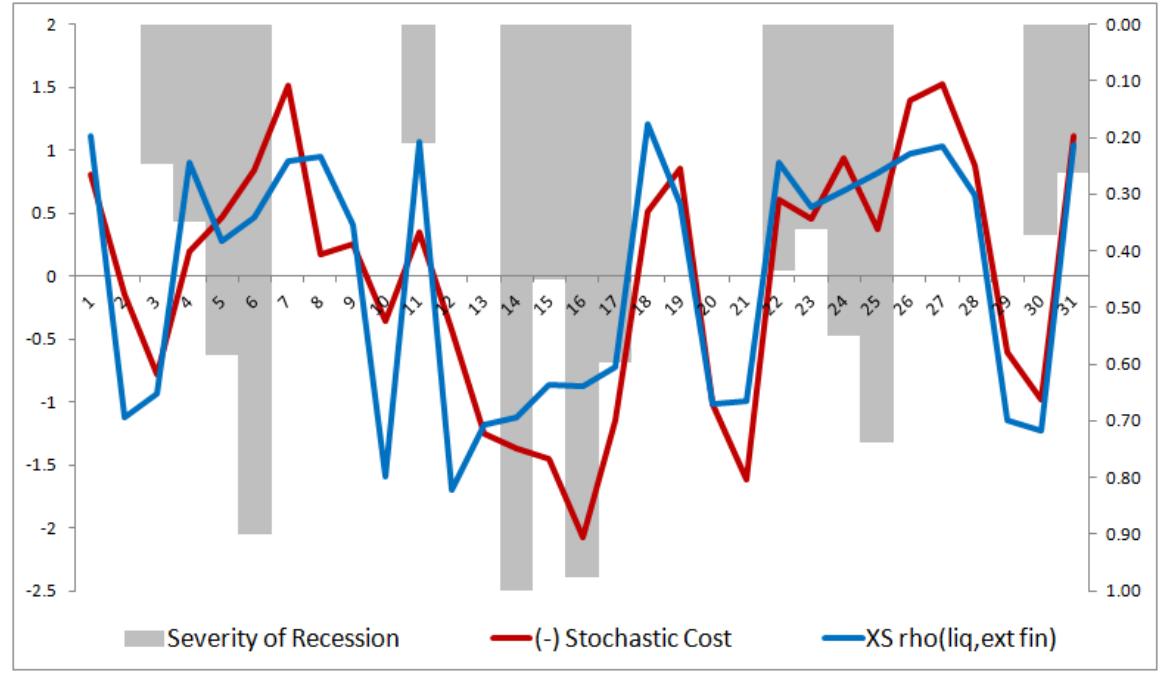

Figure 8: We plot the the cross-sectional correlation between liquidity and external finance (XS rho). In our model, this proxy reveals times when external finance is expensive, as measured by the negative of the stochastic cost of external finance $(-\ln (\xi))$. The correlation between XS rho and the negative of the log cost $(-\ln (\xi))$ is 0.80 in the model. Gray bars indicate when gdp growth falls below trend (right axis). 
external finance (-) or payoxtern(tea)l finance (-) or payexter(ta)l finance (-) or payouts (+)

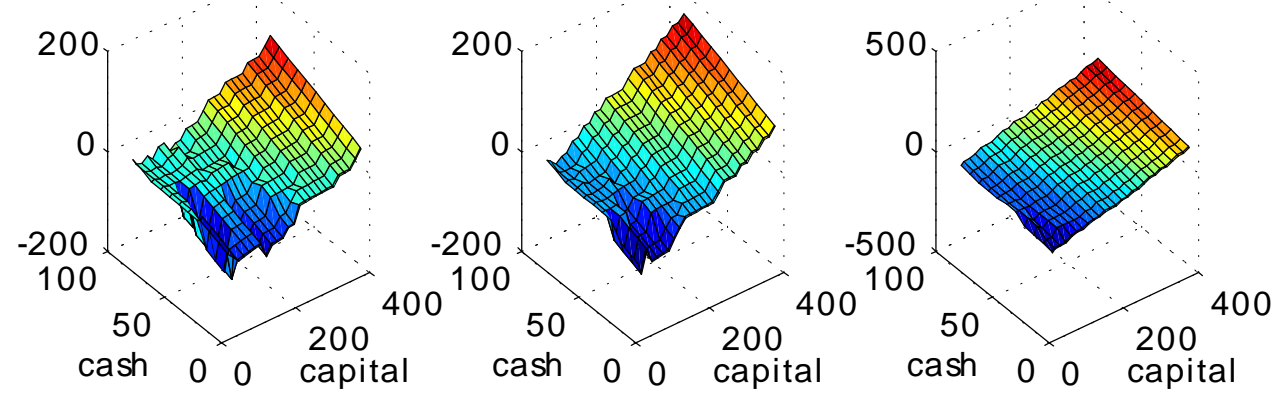

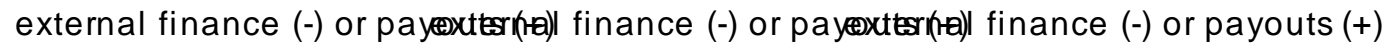

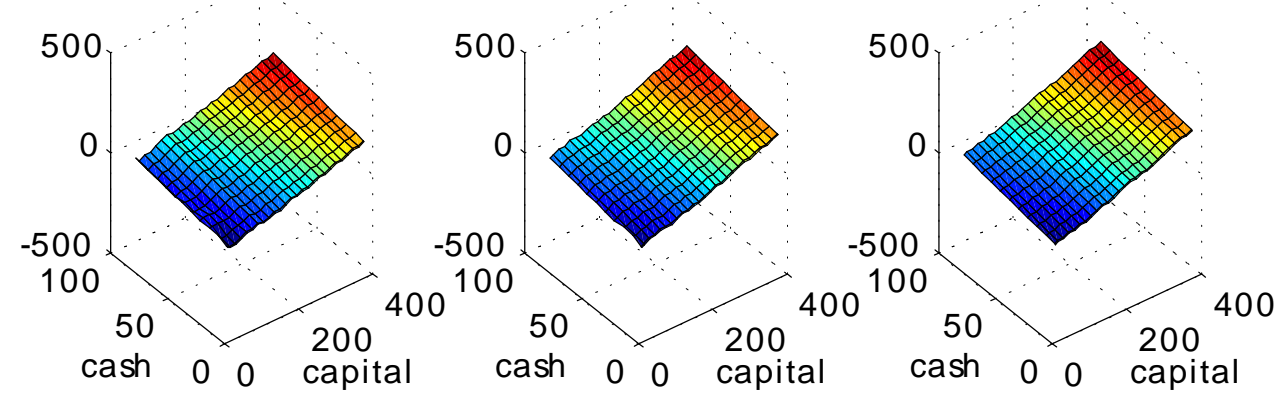

Figure 9: The figure plots external finance for various realizations of the productivity shock. When e is below zero, the firm is raising external finance, and paying out otherwise. The upper left panel is the highest productivity state, while the bottom right is the lowest. 



Figure 10: The figure plots investment for various realizations of the productivity shock. The upper left panel is the highest productivity state, while the bottom right is the lowest. 

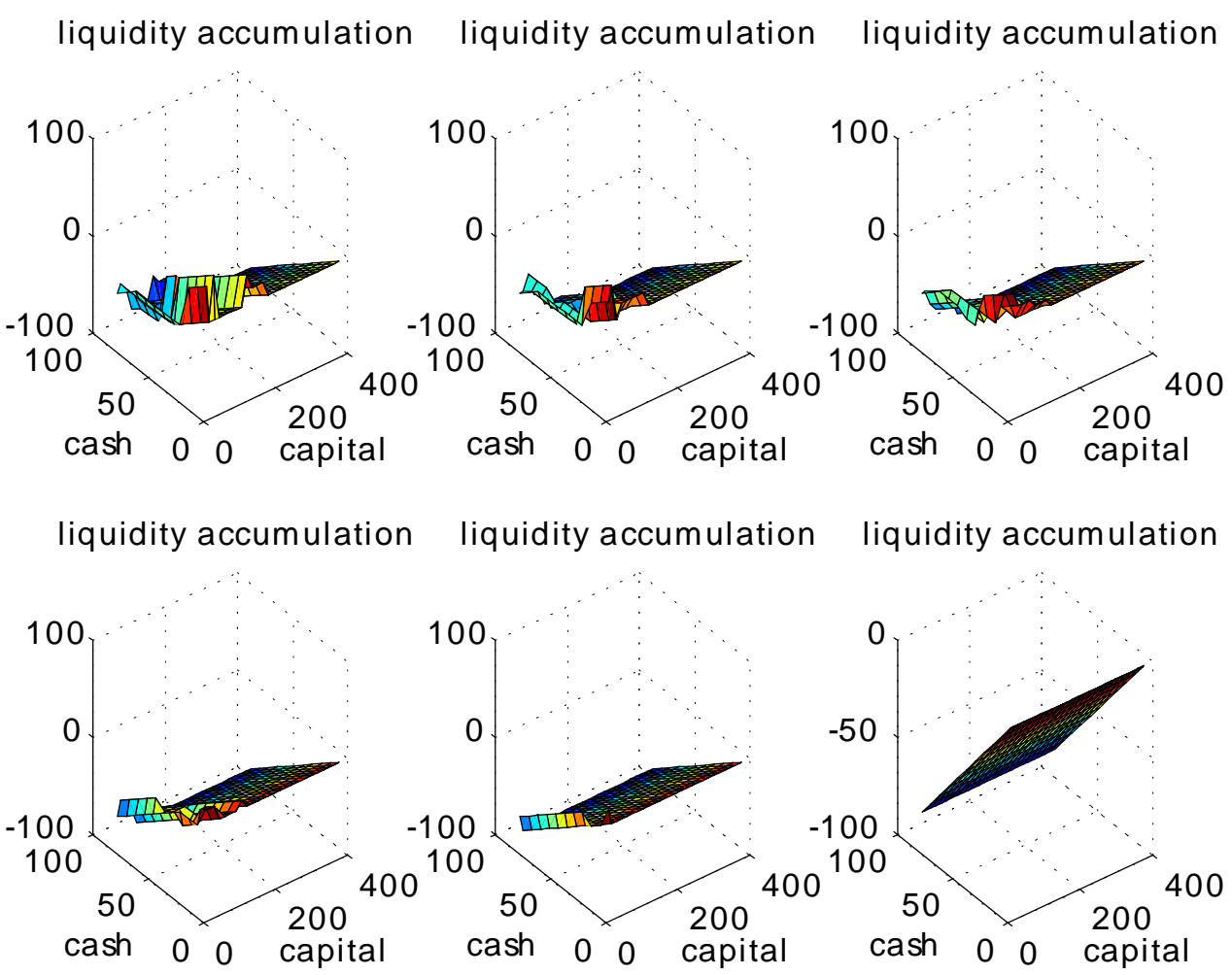

Figure 11: The figure plots liquidity accumulation for various realizations of the productivity shock. The upper left panel is the highest productivity state, while the bottom right is the lowest. 

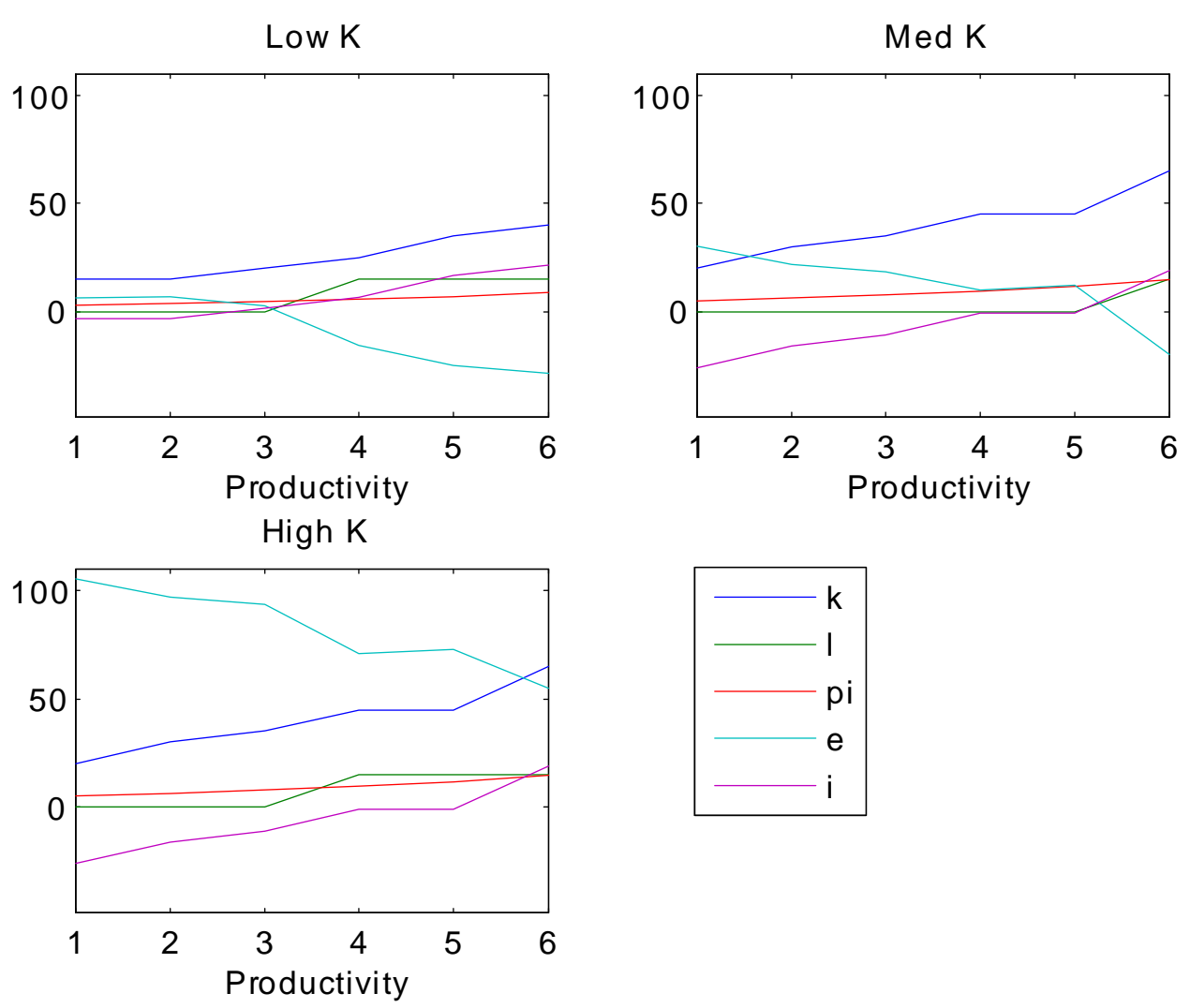

Figure 12: The figure plots the policy function for different current levels of capital. The x-axis represents the aggregate state, increasing from left to right. For example, a downward sloping line means the series is counter-cyclical and vice versa. The three panels depict the policy function for a small, medium, and large firm respectively. 

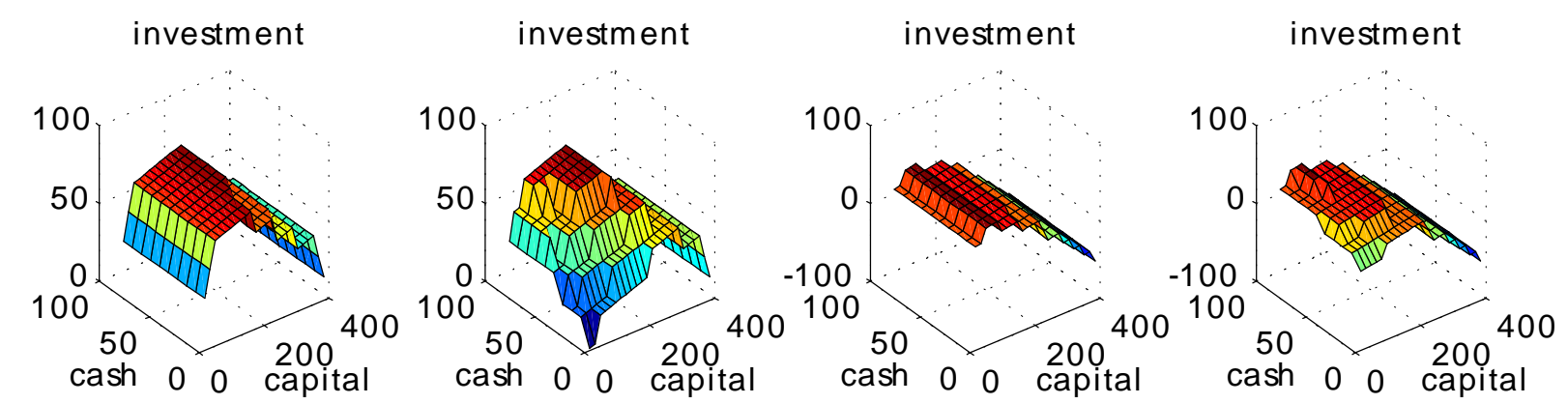

external finance $(-)$

external finance (-)

external finance (-)

external finance (-)
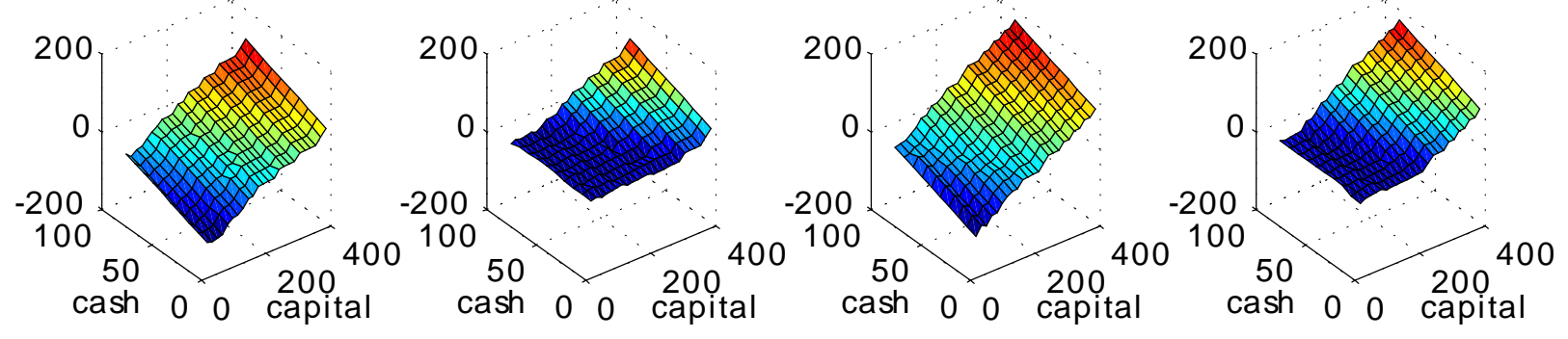

liquidity accumulation liquidity accumulation liquidity accumulation liquidity accumulation


Figure 13: The figure plots investment, external finance, and liquidity accumulation for various realizations of the productivity and stochastic cost shock. Each row gives the policy function in the (highest productivity, lowest cost), (highest productivity, highest cost), (2nd highest productivity, lowest cost), and (2nd highest productivity, highest cost) respectively as you move from left to right. We only show relatively high productivity states since these are where the cost of finance shock most strongly impacts firm policies. 
Table I: This table gives the correlation between liquidity accumulation and external finance at the firm and aggregate level and for different firm sizes. We use annual compustat data from 1980-2010. For the aggregate series, we normalize by the lag of total assets and hp-filter each series. For the firm level, we compute the average firm level correlations. The size bins are determined by total asset size. The main results in the paper focus on the $[0,90] \%$ bin. ${ }^{*}$ indicates significance at $5 \%$ level.

\section{Correlation By Size}

\begin{tabular}{lll}
\hline Moment & $\begin{array}{l}\text { Aggregate: } \\
\rho\left(\frac{\Sigma l i q a c c_{t}}{\Sigma T A_{t-1}}, \frac{\Sigma e x t_{t}}{\Sigma T A_{t-1}}\right)\end{array}$ & $\begin{array}{l}\text { Avg Firm Level: } \\
\frac{1}{N} \Sigma \rho\left(\frac{\text { liqacc }}{T A}, \frac{e x t}{T A}\right)\end{array}$ \\
\hline \hline$[0,25] \%$ & $0.59^{*}$ & $0.17^{*}$ \\
{$[25,50] \%$} & $0.87^{*}$ & $0.19^{*}$ \\
{$[50,75] \%$} & $0.70^{*}$ & $0.14^{*}$ \\
{$[75,90] \%$} & 0.29 & $0.10^{*}$ \\
{$[90,100] \%$} & 0.03 & $0.12^{*}$ \\
{$[0,50] \%$} & & $0.19^{*}$ \\
{$[\mathbf{0 , 9 0}] \%$} & $0.84^{*}$ & $\mathbf{0 . 1 8 ^ { * }}$ \\
{$[0,100] \%$} & $\mathbf{0 . 6 0}^{*}$ & $0.18^{*}$ \\
& 0.12 & \\
\hline Flow of Funds & & \\
\hline Narrow Liquidity & 0.33 & \\
Liquidity w 1/3 other & $0.38^{*}$
\end{tabular}


Table II: This table gives aggregate correlations between liquidity accumulation, external finance, and investment. We use annual Compustat data from 1980-2010. For each series, we normalize by the lag of total assets and hp-filter. "No Div" refers to non-dividend paying firms in a given year, and "No Rating" refers to firms who do not have a rating in Compustat. Each is meant to capture more constrained firms. $<90 \%$ refers to the lowest $90 \%$ of firms, our main focus. Finally FoF uses aggregate Flow of Funds data to provide corroborating evidence. * indicates significance at $5 \%$ level.

Aggregate Facts

\begin{tabular}{llll}
\hline Moment & $\rho($ liqacc, ext $)$ & $\rho($ liqacc, inv $)$ & $\rho($ ext, inv $)$ \\
\hline \hline Comp: All & 0.12 & $-0.48^{*}$ & $0.31^{*}$ \\
Comp: $<90 \%$ & $0.60^{*}$ & 0.12 & $0.46^{*}$ \\
Comp: $<50 \%$ & $0.84^{*}$ & $0.42^{*}$ & $0.67^{*}$ \\
Comp: No Div & $0.68^{*}$ & 0.30 & $0.52^{*}$ \\
Comp: No Rating & $0.56^{*}$ & 0.16 & -0.07 \\
FoF & 0.33 & -0.27 & $0.36^{*}$ \\
FoF (w 1/3 other) & $0.38^{*}$ & 0.23 & $0.36^{*}$ \\
& & & \\
Model & 0.59 & 0.45 & 0.98 \\
ModelSC & 0.58 & 0.34 & 0.95
\end{tabular}

Table III: Cylically Ajusted Aggregate Facts. We use annual Compustat data, dropping the top $10 \%$ of firms. We normalize by lagged assets and hp-filter the resulting series. We report p-values in parenthesis.

\begin{tabular}{|c|c|c|c|c|c|}
\hline \multicolumn{6}{|c|}{ Aggregate Correlations } \\
\hline invest & $\begin{array}{r}\text { liqacc } \\
0.12 \\
(0.51)\end{array}$ & invest & "external fin & debt & " equity \\
\hline external fin & $\begin{array}{r}0.60 \\
(0.00)\end{array}$ & $\begin{array}{r}0.46 \\
(0.01)\end{array}$ & & & \\
\hline debt & $\begin{array}{r}0.16 \\
(0.39)\end{array}$ & $\begin{array}{r}0.60 \\
(0.00)\end{array}$ & $\begin{array}{r}0.77 \\
(0.00)\end{array}$ & & \\
\hline equity & $\begin{array}{r}0.69 \\
(0.00)\end{array}$ & $\begin{array}{r}-0.15 \\
(0.42)\end{array}$ & $\begin{array}{r}0.43 \\
(0.01)\end{array}$ & $\begin{array}{c}-0.25 \\
(0.18)\end{array}$ & \\
\hline $\begin{array}{r}\text { operating } \\
\text { profits }\end{array}$ & $\begin{array}{r}0.30 \\
(0.10)\end{array}$ & $\begin{array}{r}0.33 \\
(0.07)\end{array}$ & $\begin{array}{r}0.56 \\
(0.00)\end{array}$ & $\begin{array}{r}0.44 \\
(0.01)\end{array}$ & $\begin{array}{r}0.23 \\
(0.21)\end{array}$ \\
\hline
\end{tabular}


Table IV: We give our calibrated parameters below along with those in Riddick and Whited (RW) and the standard business cycle literature (RBC). The label e.c.f. denotes external cost of finance and i.a. denotes investment adjustment costs. The lower panel gives the implied average costs of issuance and investment firms pay with the given parameters. For example, the implied average cost of issuance gives the average cost paid for a firm raising external finance as a fraction of the amount of funds raised.

\begin{tabular}{llllll} 
Symbol & Description & EM & EMSC & RW & RBC \\
\hline \hline$\tau$ & tax rate & 0.1 & 0.1 & 0.20 & - \\
$\delta$ & depreciation & 0.08 & 0.08 & 0.15 & 0.08 \\
$\theta$ & curvature & 0.65 & 0.65 & 0.75 & 0.33 \\
$\rho$ & persistence & 0.66 & 0.66 & 0.66 & 0.9 \\
$\sigma$ & total vol of prod & 0.121 & 0.121 & 0.121 & - \\
$\sigma_{i}$ & idiosyncratic vol & 0.11 & 0.11 & - & - \\
$\sigma_{a g g}$ & aggregate vol & 0.03 & 0.03 & - & 0.022 \\
$\lambda_{0}$ & e.c.f. fixed & 0.2334 & 0 & 0.389 & - \\
$\lambda_{1}$ & e.c.f. linear & 0.004 & 0.053 & 0.053 & - \\
$\lambda_{2}$ & e.c.f. quad & 0.00001 & 0.0002 & 0.0002 & - \\
$a$ & i.a. quad & 0.147 & 0.147 & 0.049 & - \\
$c$ & i.a. fixed & 0.01 & 0 & 0.039 & - \\
$r$ & risk-free & 0.04 & 0.04 & 0.04 & 0.04 \\
$\sigma_{\eta}$ & vol cost of funds & - & 3 & - & - \\
$\gamma$ & persistence & - & 0.4 & - & - \\
$\mu_{\xi}$ & mean credit & - & 0.4 & - & - \\
Symbol & Description & EM & EMSC & RW & RBC \\
\hline \hline$E\left[\frac{\phi_{e}(e)}{e}\right]$ & implied average & 0.017 & 0.085 & & \\
$E\left[\frac{\phi_{i}\left(i_{k}, k\right)}{i_{k}}\right]$ & issuance cost & & & & \\
& implied average & 0.009 & 0.009 & & \\
& investment cost & & & & \\
\hline
\end{tabular}


Table V: Firm Level Facts. The table gives firm level moments. In each case, we compute the relevant moment for the entire panel of firms and then take a median across firms. We use our simulated panel of data (Model column) and Compustat (Data column). We normalize the series by total book assets. * indicates significance at $5 \%$ level.

\begin{tabular}{llll} 
Firm Level Facts & & & \\
\hline Moment & Data & Model & ModelSC \\
\hline \hline E[liq lev $]$ & 0.15 & 0.01 & 0.06 \\
$\sigma($ liqacc $)$ & 0.10 & 0.07 & 0.11 \\
$\mathrm{E}[$ inv $]$ & 0.06 & 0.11 & 0.07 \\
$\sigma($ inv $)$ & 0.07 & 0.16 & 0.12 \\
$\mathrm{E}[$ ext $]$ & -0.02 & -0.07 & -0.11 \\
$\sigma($ ext $)$ & 0.17 & 0.21 & 0.17 \\
$\rho($ liqacc, ext $)$ & $0.18^{*}$ & 0.57 & 0.62 \\
$\rho\left(\iota_{\text {liqacc }}, \iota_{\text {ext }}\right)$ & $0.09^{*}$ & 0.64 & 0.48 \\
$\rho($ liqacc, inv $)$ & $-0.06^{*}$ & 0.22 & -0.00 \\
$\rho($ ext, inv $)$ & $0.20^{*}$ & 0.93 & 0.77 \\
prob(raise funds $)$ & 0.43 & 0.15 & 0.17
\end{tabular}


Table VI: This table gives aggregate facts for the model (both baseline and stochastic costs (SC) versions) using a simulated panel of firms. We then compare this panel with annual Compustat data, 1980-2010. The sample excludes financial firms, utilities, non-profits, the top $10 \%$ of firms based on asset size, and firms with missing assets, ppe, or cash balances. For correlations, we normalize each series by lagged assets and apply the hp-filter. All other series are normalized by current assets. * indicates significance at $5 \%$ level.

\begin{tabular}{llll} 
Aggregate Facts & & & \\
\hline Moment & Data & Model & ModelSC \\
\hline \hline $\mathrm{E}[$ liq lev $]$ & 0.11 & 0.03 & 0.06 \\
$\sigma($ liq $)$ & 0.03 & 0.05 & 0.01 \\
$\sigma($ liqacc $)$ & 0.01 & 0.01 & 0.01 \\
$\mathrm{E}[\mathrm{i}]$ & 0.07 & 0.08 & 0.08 \\
$\sigma($ inv $)$ & 0.01 & 0.03 & 0.04 \\
$\mathrm{E}[$ ext $]$ & -0.01 & -0.10 & -0.10 \\
$\sigma($ ext $)$ & 0.03 & 0.03 & 0.04 \\
$\rho($ liqacc, ext $)$ & $0.60^{*}$ & 0.59 & 0.58 \\
$\rho($ liqacc, inv $)$ & 0.12 & 0.45 & 0.34 \\
$\rho($ ext, inv $)$ & $0.46^{*}$ & 0.98 & 0.95 \\
prob(raise ext) & 0.43 & 0.15 & 0.17 \\
prob(agg shortfall $)$ & 0.05 & 0.01 & 0.004
\end{tabular}

Aggregate Facts: Cyclicality

\begin{tabular}{llll}
\hline Moment & Data & Model & ModelSC \\
\hline \hline$\rho($ liqacc, gdp $)$ & 0.00 & 0.41 & -0.07 \\
$\rho($ ext, gdp $)$ & $0.28^{*}$ & 0.99 & 0.84 \\
$\rho($ inv, gdp $)$ & $0.47^{*}$ & 0.97 & 0.70
\end{tabular}


Table VII: This table evaluates the proxies for the cost of external finance given in our model. XS rho(liqacc,ext) is the cross-sectional correlation between liquidity and external finance at each date. When this measure is high, external finance is cheap. The \% Firms Raising external finance also increases when financing is cheap. We compute correlations of these variables with empirical proxies for our two shocks. We use the default spread as the stochastic cost of external finance, and the total factor productivity series provided by John Fernald as TFP. * indicates significance at 5\% level.

\section{Correlations}

\begin{tabular}{llll}
\hline XS rho(liqacc,ext) & Data: & Model & ModelSC: \\
\hline \hline Stoch Cost $(\xi)$ & $0.64^{*}$ & - & 0.80 \\
TFP $\left(z_{\text {agg }}\right)$ & $0.48^{*}$ & 0.72 & 0.00 \\
& & & \\
\% Firms Raising & Data: & Model & ModelSC: \\
\hline \hline Stoch Cost $(\xi)$ & $0.59^{*}$ & $\overline{-}$ & 0.70 \\
TFP $\left(z_{\text {agg }}\right)$ & 0.25 & 0.85 & 0.18
\end{tabular}


Table VIII: Aggregate correlations conditional on firms raising or paying out funds (top panel) and firm size (bottom panel). The data uses Compustat firms and all aggregate variables are normalized by lagged total assets. Firms are raising funds if external finance is positive. We aggregate firms in a given group each year. * indicates significance at $5 \%$ level.

\begin{tabular}{|c|c|c|c|}
\hline \multicolumn{4}{|c|}{$\operatorname{Corr}\left(\frac{\operatorname{LiqAcc}}{T A}, \frac{X}{T A}\right)$} \\
\hline Variable & Data & Model & Model SC \\
\hline \multicolumn{4}{|c|}{ Conditional on Raising funds: $\mathrm{e}<0$} \\
\hline debt & $0.33^{*}$ & - & - \\
\hline equity & $0.77^{*}$ & - & - \\
\hline external fin & $0.74^{*}$ & 0.91 & 0.82 \\
\hline invest & $0.37^{*}$ & 0.79 & 0.55 \\
\hline cfo & 0.29 & 0.63 & 0.54 \\
\hline \multicolumn{4}{|c|}{ Conditional on paying out funds: $\mathrm{e}>=0$} \\
\hline debt & -0.16 & - & 一 \\
\hline equity & 0.26 & - & - \\
\hline external fin & 0.15 & 0.15 & 0.45 \\
\hline invest & -0.16 & -0.33 & 0.10 \\
\hline cfo & -0.13 & -0.26 & 0.65 \\
\hline \multicolumn{4}{|c|}{ Corr $\left(\frac{L i q A c c}{T A}, \frac{E x t F i n}{T A}\right)$ Conditional on Size: } \\
\hline Size & Data & Model & ModelSC \\
\hline$[0,25] \%$ & $0.59^{*}$ & 0.94 & 0.94 \\
\hline$[0,50] \%$ & $0.84^{*}$ & 0.86 & 0.92 \\
\hline$[0,90] \%$ & $0.60^{*}$ & 0.60 & 0.76 \\
\hline$[90,100] \%$ & 0.03 & 0.20 & 0.12 \\
\hline
\end{tabular}

